\title{
LA SALA DE MILLONES Y LA REPRESENTACIÓN DEL REINO EN EL REINADO DE CARLOS II*
}

\author{
The Sala de Millones and the representation of the kingdom \\ in the reign of Carlos II
}

\author{
BEATRIZ CÁRCELES DE GEA**
}

Recibido: 06-12-2017

Aprobado: 03-11-2020

\section{RESUMEN}

En este trabajo realizamos un recorrido por la historia de la Comisión de Millones durante el reinado de Carlos II por intercesión de dos pleitos. Con ellos veremos aflorar una doble interpretación del derecho que hace variar el significado de la institución. Una se enmarca en su condición de representante del reino, con su sistema de referencia legal correspondiente a las escrituras de millones, al pacto fiscal; otra se adscribe a su subordinación al Consejo de Hacienda, a sus leyes y ordenanzas, brazo ejecutor de un rey que se presenta como pater familias, según una potestad económica que lo desliga de la ley y el derecho.

Palabras claves: impuestos; Asambleas; Servicio de millones.

\section{ABSTRACT}

In this paper, we will explore the history of the Comisión de Millones during the reign of Carlos II through the mediation of two legal proceedings. We will see a double interpretation of the law which makes the meaning of the institution change. One is within its nature as representative of the kingdom, with its legal system corresponding to the escrituras de millones and to the fiscal covenant, while the other concerns its subordination to the Treasury Council, with its laws and ordinances, as the enforcement arm of a king who presents himself as pater familias, according to an oeconomicae which separates it from justice and the law.

Keywords: Taxes; Assemblies; Fiscal covenant.

\section{INTRODUCCIÓN}

El debate historiográfico surgido en los últimos decenios sobre la representación del reino en la Edad Moderna, con sus distintas instituciones, y específicamente sobre el papel desempeñado por el servicio de millones en su devenir, dada su vitalidad en la constitución castellana, se caracteriza por considerarlo, por un lado, como un signo de su fortaleza, y como el paradigma

* Este trabajo se ha llevado a cabo con el proyecto HAR2013-45788-C4-2-P del Ministerio de Economía, Industria y Competitividad.

** CSIC. beatricecar@gmail.com 
de la naturaleza contractual de las relaciones entre rey y reino ${ }^{1}$; por otro lado, debido a su supuesto fracaso, o a su desenlace, como una evidencia de la implementación de una monarquía de signo autoritario o absoluto en esas centurias $^{2}$. En este trabajo veremos enfrentados a los ministros en una batalla legal suscitada alrededor de la Sala de Millones en el reinado de Carlos II. La trascendencia de los argumentos aportados se adscribía a la encarnación del ius - representado en esta ocasión por las escrituras de millones-, o a su negación. Estaba en juego, en efecto, con la condición y proyección política de la institución, la substancia del derecho, y con ella la naturaleza misma de la monarquía.

Desde las reformas de 1632, y especialmente en 1639 con su institución como tribunal supremo, hasta su incorporación al Consejo de Hacienda, en 1658 — que ya se consideró en 1643, y se intentara en las Cortes de 1645-1647-, a

1. Miguel Artola, La hacienda del antiguo régimen (Madrid: Alianza, 1982), 91, 108. Pablo Fernández Albaladejo, los trabajos recogidos en Fragmentos de monarquía (Madrid: Alianza, 1992), 241-349. José Ignacio Fortea, "Trayectoria de la Diputación de Cortes", en Las Cortes de Castilla y León en la Edad Moderna. Actas de la segunda etapa del Congreso Cientifico sobre la Historia de las Cortes de Castilla y León, Salamanca, del 7 al 10 de abril de 1987 (Valladolid: Cortes de Castilla y León, 1989), 73; "Reino y Cortes: el servicio de millones y la reestructuración del espacio fiscal en la Corona de Castilla (1601-1621)", en Política y Hacienda en el Antiguo Régimen. II Reunión cientifica Asociación Española de Historia Moderna 1992, eds. José Ignacio Fortea Pérez, Carmen María Cremades Griñán (Murcia: Ediciones de la Universidad de Murcia, 1993), 53-82; Las Cortes de Castilla y León bajo los Austrias: una interpretación (Valladolid: Junta de Castilla y León, 2008), 50. Juan Luis Castellano, Las Cortes de Castilla y su Diputación (1621-1789). Entre pactismo y absolutismo (Madrid: Centro de Estudios Constitucionales, 1990), 59. Irving A. Anthony Thompson, "Crown and Cortes in Castile, 1590-1665," en Crown and Cortes. Government, Institutions and Representation in Early-Modern Castile (London-New York: Routledge, 1993), VI: 29-45. Sobre la vitalidad de la representación del reino y de las Cortes conforme a la constitución de Castilla, Charles David Hendricks, "Charles V and the "Cortes' of Castile. Politics in Reinaissance Spain" (Tesis Doctoral, Cornell University, 1976).

2. Salustiano de Dios, "La evolución de las Cortes de Castilla durante los siglos XV-XVII," en Hispania. Entre derechos propios y derechos nacionales. Atti dell'incontro di studio. Firenze-Lucca, 25, 26, 27 maggio 1989, eds. Bartolomé Clavero, Paolo Grossi, Francisco Tomás y Valiente (Milano: Giuffrè Editore, 1990), I: 706-707. Charles J. Jago, "Fiscalidad y cambio constitucional en Castilla (1601-1621)," en Actas de la II Reunión Científica de la Asociación Española de Historia Moderna (Moratalla: Universidad de Murcia, 1993), 1: 117-132. Emiliano Fernández de Pinedo y Fernández, "Fiscalidad y absolutismo en Castilla en la primera mitad del siglo XVII," en Política y Hacienda en el Antiguo Régimen, 33-51. Para el siglo XVI, sobre el papel limitado desempeñado por las Cortes, Joseph Pérez, La revolución de las Comunidades de Castilla (1520-1521) (Madrid: Siglo Veintiuno de España, 1979), 67-69. El fracaso de las Cortes en mantener una relación contractual entre rey y reino, ha sido defendida por Benjamín González Alonso, "Las Comunidades de Castilla y la formación del estado absoluto," en Sobre el estado y la administración de la Corona de Castilla en el antiguo régimen (Madrid: Siglo Veintiuno de España, 1981), 55. Compárese también, Juan Manuel Carretero Zamora, Cortes, monarquía, ciudades. Las Cortes de Castilla a comienzos de la época moderna (1476-1515) (Madrid: Siglo Veintiuno de España, 1988), 11.

Chronica Nova, 46, 2020, 177-212 - http://doi.org/10.30827/cnova.v0i46.6644 
medida que avanzaba la reforma administrativa de la hacienda, la historia de la Comisión de Millones había ido fortaleciéndose a la vez que perdía su representación del reino. La incorporación se presentaba como la culminación de ese proceso. Pero el hecho de que se mantuvieran las condiciones de millones - lo que no excluía su contravención o dispensa, que no era sino una manifestación más de la desobligación del $i u s^{3}$ —, ofrecía todo un sistema de referencia legal adscrito a los valores contractuales del auxilium, listo para ser recuperado y activarlo a favor de los intereses del reino, cuando la ocasión lo requiriese. Ello no se detuvo después de 1658, tampoco en el reinado de Carlos II $^{4}$. El consentimiento necesario de las ciudades para la prorrogación del servicio era su principal baza — una práctica, ya experimentada antes, que se justificó con la urgencia de la necesidad ${ }^{5}$ — ; ello sin olvidar la competencia de la Sala de Mil y Quinientas del Consejo de Castilla en materia de contravención de las escrituras. La consecuencia era que no se había desatado absolutamente la representación del reino en la Sala, seguía latente. Es así como con los pleitos que presentamos en este trabajo, uno iniciado al finalizar el reinado de Felipe IV, en 1663, otro

3. Ello se produjo ya durante el reinado de Felipe IV, unas veces con acuerdo del reino, como en 1632, en cuanto a la prohibición de vender oficios de receptorías y escribanías de millones, otras de la mano de algunos administradores generales del servicio. La dispensa incluso la encontramos en los ofrecimientos hechos para arrendamientos de millones por asentistas, como fue el caso de Francisco Báez Eminente, en 1649, no obstante que se dio la renta a Martín Rodríguez de la Vega. Asimismo apoyaba la pretensión el asentista, en cuanto a su derecho a los prometidos, alegando que ello era sin embargo de cualesquiera leyes y condiciones de millones, Pedro de Porres Enríquez, "Por Francisco Báez Eminente con el señor fiscal de la Junta de Millones del reino, sobre los prometidos que ganó en la postura que hizo en las rentas de los servicios de millones del reino de Galicia”, Biblioteca Nacional de Madrid (en adelante BN), Porcones, 249(2).

4. Compárese José Ignacio Fortea, "Monarquía, Cortes y ciudades en la Corona de Castilla durante la Edad Moderna," en Actes del 53 Congrés de la Comissió Internacional per a l'Estudi de la Història de les Institucions Representatives i Parlamentàries, coords. Jaume Sobrequés, Joseba Agirreazkuenaga, Mercè Morales, Mikel Urquijo, M. Cisneros (Barcelona: Parlament de Catalunya y Museu d'Història de Catalunya, 2005), 342-345. José Luis Bermejo Cabrero, "En torno a las Cortes del antiguo régimen," AHDE (Anuario de Historia del Derecho Español), no 63-64 (1993-1994): 175, 216. Es significativo, por ejemplo, el hecho que recoge Antonio Domínguez Ortiz, cuando, en 1698, los capitulares de Plasencia y Alcántara, puesto que no se habían convocado Cortes, pidieron se les autorizase a entrar en la Comisión de Millones, lo que muestra la continuidad de su percepción como instancia de representación del reino, Antonio Domínguez Ortiz, "Concesiones de votos en Cortes a ciudades castellanas en el siglo XVII," AHDE, no 31 (1961): 185-186. Irving A. Anthony Thompson, "The end of the Cortes of Castile," en Crown and Cortes. Government, Institutions and Representation in Early-Modern Castile, VII: 125-133. Fernández Albaladejo, "Monarquía, cortes y cuestión constitucional en Castilla durante la Edad Moderna" en Fragmentos de monarquía, 299.

5. Por ejemplo, con motivo de la perpetuación del servicio de los 8 mil infantes, el pedido a la ciudad de Sevilla, 23 de octubre de 1653, firmado por el conde de Villaumbrosa, BN, VE, 1548/2. La primera vez que se acudió a esta comunicación directa fue en 1645, Fernández Albaladejo, "La resistencia en las Cortes" en Fragmentos de monarquía, 347. 
en 1681, veremos que la Comisión se podía prestar a una doble interpretación plenamente vigente durante el reinado de Carlos II. En efecto, con los argumentos que aportaron los protagonistas se revelan dos probabilidades legales: una la de una Sala o Comisión representante del reino, baluarte de sus intereses; otra la de una Comisión subordinada al Consejo de Hacienda, como agente de una ley fiscal económica o absoluta, desligada de las obligaciones de la ley del reino y del derecho. Con esa ambivalencia ambos pleitos nos muestran una pugna en la que estaba en juego el valor relativo y ordinario de la ley fiscal, su ajuste y eventual contravención conforme a derecho, con la peculiaridad de que ello sucedía al interior de un mismo tribunal, el Consejo de Hacienda.

\section{LA REPRESENTACIÓN DEL REINO}

El 19 de junio de 1663, habiéndose juntado el reino en Cortes, resolvió se moviese pleito en la Sala de Mil y Quinientas del Consejo de Castilla, sobre separar la Comisión de Millones del Consejo de Hacienda. El 11 de septiembre del mismo año, un procurador presentaba en las Cortes una proposición para extinguir la Diputación ${ }^{6}$. Se pretendía agregarla a la Comisión de Millones ${ }^{7}$. Ambos acontecimientos pueden bien interpretarse como el deseo de fortalecer a una Comisión con plena representación del reino $^{8}$, y forjar así su independencia de Hacienda. Alegaba el agente en el primer caso, que el acuerdo, de 27 de marzo de 1658, fue nulo, porque se hallaron cuatro procuradores de Cortes que eran del Consejo de Hacienda, y porque los que votaron no tenían poderes bastantes de las ciudades para contravenir las condiciones de millones, además de que no se cumplían “...las con que se había hecho la agregación”". Por el acuerdo de 1658 el reino prestaba su consentimiento “...dispensando en las condiciones de millones, y otro cualquier derecho..."10; seguían siendo tenidas en cuenta, salvo en lo que fueren contrarias al acuerdo. Su Agente pedía entonces ser manutenido en la posesión de consultar las administraciones, y tener voto en

6. Bermejo Cabrero, "En torno a las Cortes del antiguo régimen", 201ss.

7. Fortea, "Trayectoria de la Diputación de Cortes", 41. Bermejo Cabrero, "En torno a las Cortes del antiguo régimen", 203.

8. Bermejo Cabrero, "En torno a las Cortes del antiguo régimen", 197.

9. "El licenciado don Tomás Jiménez Pantoja, fiscal del Real Consejo de Hacienda, con el agente y procurador general del reino... sobre si la Comisión de Millones del reino, que está unida y agregada a dicho Consejo de Hacienda, haya de separarse de él y reducirse a su antiguo gobierno" (1668), Archivo Histórico Nacional (en adelante AHN), Consejos, leg. 25.865.

10. "Acuerdo que el reino hizo en 27 de marzo de 1658, dando consentimiento para que la Comisión de Millones pasase de donde estaba, y se agregase, y uniese con el Consejo de Hacienda...", BN, VE, 39/35, f. 4v. 
las de justicia. En 1668, alegaba Tomás Jiménez Pantoja, fiscal del Consejo de Hacienda, que el agente del reino estaba mal informado en aquel año, pues las administraciones generales se consultaban, y los comisarios del reino votaban en los pleitos de justicia "siendo esto voluntario, como se previene en todas las condiciones de servicios, y votan, como si fueran jueces letrados". Alrededor de las administraciones se estaba dirimiendo el control del servicio de millones, la representación del reino, con el mantenimiento de los principios pactistas del auxilium en las ciudades. Mientras que el acto voluntario, siendo conforme a derecho, podía sin embargo servir para desnaturalizar la institución.

Afirma Tomás Jiménez Pantoja que, en 1646, con motivo del intento de incorporar la Comisión de Millones al Consejo de Hacienda, su presidente escribió un papel al reino, el 30 de julio, representando lo poco que producían los servicios concedidos, la gran necesidad en la que se encontraba la monarquía, y los grandes gastos que se causaban corriendo su administración en la forma en la que estaban, pues llegaba a alcanzar dicha administración más de 30.000 ducados cada año. Defendía que, reducida al Consejo de Hacienda, correría con más inteligencia, y habría más fácil expediente en los negocios. En él podría conocerse de todas las materias de gobierno, de las de justicia en el tribunal de oidores, de las de cuentas en la Contaduría. El reino acordó se hiciese una súplica al rey para que no innovase. La cédula del rey, de 20 de marzo de 1647, por la que se establecía dicha incorporación, dio motivo al pleito que el procurador del reino puso, pretendiendo se habían de guardar las condiciones de millones. Si se hacía hincapié en el gasto, vemos que con esa primera tentativa de incorporación el objetivo era implantar una nueva forma de gobierno y administración, la que concernía a la "mayor inteligencia", y al "fácil expediente". Tomás Jiménez Pantoja esgrimía a este respecto que

...el consentimiento que dio el reino para que la Comisión de Millones se agregase al Consejo de Hacienda, no fue otra cosa, que quitar los pactos que daban diferente forma de administración, y poner otros en su lugar, que en la unión habían de observarse.

Por tanto, en 1658, había subversión y nueva forma. La "mayor inteligencia", y quitar el lastre de esos pactos, apuntaba también al control de las cuentas por la Contaduría. Si bien añadía el fiscal de Hacienda: "quedando el contrato de la donación, y servicio que el reino hizo a su majestad en el mismo ser, y estado, sin más variación, que la de esta circunstancia”. Quedaba el servicio hecho al rey, pero la nueva forma administrativa revolucionaba la fiscalidad y el derecho. Para el presidente con la unión, en 1646, no se trataba de mantener la independencia de la Comisión, su condición de tribunal supremo, sino su fusión con el Consejo de Hacienda. Sin embargo, en 1668, el fiscal hace hincapié en que “... el estado de jurisdicción que tenía esta Junta, cuando hizo tránsito al Consejo 
de Hacienda en el año de 1658, fue estar independiente...". Asimismo recalca que cuando la Comisión estaba en el Consejo de Castilla “....usaba de jurisdicción de tribunal superior, independiente del Consejo, y de todos los demás, y con inhibición de ellos". El fiscal lo utilizaba para demostrar que no se estaba controvirtiendo punto alguno de jurisdicción que tocase al Consejo de Castilla, porque “...la suya no se ejercía en dicha Junta...". No está defendiendo Tomás Jiménez Pantoja abiertamente un rey absoluto - aunque sí lo hace de forma simulada-, pues señala que éste no usa “...de la potestad absoluta, sino de la regular, y por eso en nuestra España han merecido el renombre de católicos". Pero el poder ordinario del rey, con su razón espiritual, solo es una cobertura. Defiende que a la potestad suprema del monarca competía la erección y creación de tribunales, salas y gobierno de ellas, formaba parte de las regalías. La existencia de la Comisión o Sala no era, por tanto, el fruto de un pacto. El agente del reino alega que no se estaba observando lo que se guardaba en el Consejo de Castilla. Si no había ese punto de jurisdicción del Consejo, el reino estaba añorando la independencia de la Sala de Millones y su estatus de tribunal supremo, como fuera establecido en 1639, pues el hecho es que en 1658 el rey había mandado "....agregar la administración de dicha hacienda a una sola jurisdicción y a una sola cabeza, como la del Consejo de Hacienda, y su presidente". Tomás Jiménez Pantoja añade que dar jueces adjuntos a la Comisión, sean del Consejo de Hacienda, o del de Castilla, es acto facultativo y propio de la majestad real, querer limitarlo “...es pretensión de dar no justamente margen a su dilatado poder". Esa dilatación excede de nuevo una relación pactista. Defiende además que con la agregación el rey hacía uso de la regalía; era una cuestión de voluntad, además de jurisdiccional, y si pidió consentimiento al reino, fue por esperar alguna representación, que se presentasen motivos, no por ser precisa “...en resolución tan libre”. Despoja a esa representación de su esencia: la desobediencia jurídica. La libertad que esgrime el fiscal, aunque no lo reconozca, apunta a una potestad absoluta, no a la regular y ordinaria que argumentaba. Además, llega a usar el concepto. Refiriéndose a la agregación de la Sala de Millones al Consejo de Hacienda, la califica con el hecho de que convocar Cortes es facultativo del príncipe, pues puede estatuir sobre ello con "libertad absoluta". Está negando la obligación ordinaria de esa convocatoria; la libertad que la induce desobliga, no compele, si lo hace se transforma en potestad absoluta. Por oposición a ella está el cautiverio del pacto y juramento, “...aun con la real voluntad, como incapaz de sujeción alguna”. Aprovecha el fiscal la carencia de compulsión para desligar al rey de su sujeción a derecho. Hay, efectivamente, potestad absoluta. Para crear su obligación el fiscal se funda en la justicia, pues defiende que la agregación fue “....más por acto necesario de justicia, que facultativo de gracia". De ello deduce que el consentimiento del reino no era preciso. Con esa necessitas, ella sí precisa, niega la desobligación, luego está negando, en nombre de la justicia, el derecho. Además, los 
procuradores que dieron su consentimiento tuvieron poderes decisivos, es decir, poderes absolutos que desvinculaban a la Sala de las ciudades, de su soberanía. A ello añade, que “...todos los contratos se entienden paccionados, según el tiempo, y estado en que se celebran, y que llegando a ser nocivos, deben reformarse...". La potestad regular para reformar sin consentimiento del reino que esgrime es de nuevo potestad absoluta. Si esta potestas se esconde en el derecho ordinario, la realidad es que esa reforma desata el ius. A partir de la agregación el sistema de referencia de la Sala es la nueva forma, la ausencia de cautiverio, la de un rey que es "padre económico" -esta vez no esconde el nombre-, con una económica sin derecho. Iguala el poder temporal del príncipe al espiritual del papa, "y así como el pontífice es sobre el concilio, así el príncipe es sobre las Cortes". Es decir: sobre la ley del reino y el derecho; ese "padre económico" es un rey absoluto. Para el fiscal la Sala de Millones no ha perdido su estatus de tribunal supremo, pues despacha sus provisiones en el nombre real, en la misma conformidad y con la propia autoridad que tenía en el Consejo Real. Menciona el fiscal la queja del reino en cuanto a que “...no había división de contadores, relatores, y otros ministros; y que despachaban los del Consejo de Hacienda, cuya confusión causaba grave perjuicio". Para el reino esta ausencia de división anulaba la condición de tribunal supremo y su independencia del Consejo de Hacienda. Aquel estatus era ficticio.

Si acudimos a lo que piensa un contador en materia de cuentas, sobre su separación o división en los partidos, Alonso Barbero Teniente, contador de las rentas reales de Jaén y tesorería de Trujillo, en una pequeña obra que dedica a Francisco de Segura, quien por su parte había sido contador de la superintendencia general de las rentas reales y servicio de millones del reinado de Jaén, y según la planta que se observó hasta el año de 1687, advierte de que,

...todo está sujeto a la cuenta, pero la más clara, y que no puede servir de confusión, es llevarla separada, y distinta; y este ha sido el estilo general de Contadurías, y lo previenen las órdenes, porque en cada renta hay su situado, y es preciso atender a su valor: además de esto, que mezclando las rentas, se ocasionaba grande confusión; y si habiendo separación es contingente el yerro, más natural se puede cometer en un caos, y los servicios de millones pudieran correr todos en un libro, llevando la cuenta de lo que en cada paga corresponde a cada uno, pero como refiero, se deben seguir estas separaciones ${ }^{11}$.

La separación de cuentas en los partidos, nutrida por la división en las Contadurías, no puede desvincularse de la situación de la deuda. Ante la pregunta “¿Cómo debe el contador tener la cuenta, y razón del situado?”, responde

11. Alonso Barbero Teniente, Luz y claridad para contadores de partidos (Madrid: 1694), 2. 
"Formando por la relación por antelación, un libro de juros en cada renta" 12 . Los hombres de negocios se quejaban de la forma en la que tenían divididas las libranzas y consignaciones, lo que les impedía la cobranza, y habían pedido durante el reinado de Felipe IV se dividiesen — aunque fuesen de diferentes géneros-, por partidos enteros ${ }^{13}$. Ello en las ciudades.

Por lo que se refiere a la queja de ausencia de división de las cuentas en la corte, no por cuestiones técnicas, sino de servicio, es decir, políticas, contesta Tomás Jiménez, que en la Sala hay relator nombrado solo para ella, y que hay contadores de millones, separados con mesas distintas, pero añade,

Y cuando los relatores, y contadores del Consejo de Hacienda, interviniesen en las relaciones de los pleitos, y ajustamiento de cuentas, fuera de mayor conveniencia para el real servicio, causa pública, y breve expediente de los negocios; y no por eso causará nulidad como actos de mero hecho, que los puede ejercer cualquiera a quien los cometan, sin que las dichas cuentas tomadas en la Contaduría Mayor, hagan cosa juzgada, ni queden, aprobadas por el tribunal ${ }^{14}$.

Si las cuentas tomadas en la Contaduría Mayor no hacían cosa juzgada, y ello podía representar una garantía, sí había fusión; la necessitas, su razón de estado, que "...tiene su origen en la tiranía...", la que Pio V “...llamaba muy justamente razón del diablo" ${ }^{15}$, su "ley tiránica" 16 , podía neutralizar la independencia. Otra queja del reino era que los alcances de cuentas procedidos del servicio se habían mandado poner en poder del tesorero de alcances de la Contaduría Mayor, extremo que niega el fiscal, porque dice entran en poder del tesorero de millones para la paga de sus contadores, pero con una salvedad, "y si en algún tiempo, por órdenes del presidente, se hubiere aplicado alguna suma a otro fin, no es contra lo capitulado, pues por esta mano ha de correr toda la distribución, según los pactos y reales órdenes". El presidente le arrebata a la Sala la supremacía. Pero, en el acuerdo de la agregación de 1658, se establecía "Y con que las Contadurías del Reino han de quedar con el mismo ejercicio que hoy tienen". Establecía asimismo el acuerdo:

$\mathrm{Y}$ en cuanto a la distribución del caudal que se administrare por esta Sala, no pueda hacerse por el Consejo de Hacienda; porque en cuanto a esto, como

12. Barbero Teniente, Luz y claridad, 3.

13. Cédula Real, ([18] de agosto de 1654), BN, VE, 142/54.

14. "El licenciado don Tomás Jiménez Pantoja, fiscal del Real Consejo de Hacienda...", f. 24r.

15. "Idea del libro de gobierno de estado y guerra de Jerónimo Fraquetta, con los discursos suyos, el uno cerca de la razón de estado, y el otro tocante a la razón de guerra" (La BN data su publicación en siglos XVII-XVIII), BN, Mss 10.431, f. 113r.

16. Charles-Bon-François Boscheron des Portes, Histoire du Parlement de Bordeaux depuis sa création jusqu'à sa suppression (1451-1790) 2 (Bordeaux: Hachette livre-BNF, 1877), 52.

Chronica Nova, 46, 2020, 177-212 - http://doi.org/10.30827/cnova.v0i46.6644 
en todo lo demás dependiente de ello, ha de quedar inhibido, como los demás tribunales, y solamente se ha de hacer la distribución en virtud de órdenes de su majestad, y despachos por la Secretaría de esta Sala ${ }^{17}$.

Extremo que para el reino se había alterado. Y es que, en cuanto a las condiciones resolutivas de la agregación, afirma Francisco Gabriel Mestre, "no hay alguna que no esté vulnerada", "pues si mira a ser tribunal supremo, e independiente, está embebido en el Consejo de Hacienda...”; a ello añadía que “...contratar con el reino para la concesión, y no le cumplir la condición, que es resolutiva del contrato, no cabe en la disposición de derecho...". El contrato entre rey y reino es plenamente derecho, no puede haber otra supremacía que él. Continúa Mestre denunciando específicamente en materia de contabilidad, y "...si a la convocatoria de cuentas, y que sean en las Contaduría del reino, nada se le cumple", todo con el resultado "...con que el reino, sus ciudades, y Junta, solo le ha quedado lo oneroso, de que los vasallos contribuyan en estos servicios, y lo honorífico que fue correspondiente a la concesión, sin ejercicio, y como si no lo tuviese" ${ }^{18}$. La Sala de Millones como institución del reino era una ilusión. Había contravención manifiesta, un proceder contra derecho, también subordinación al presidente —estaba "embebido"-; o, si de nuevo circunstancial, había momentos de fusión, lo cual era suficiente para negarle su estatus de tribunal supremo. Una cuarta queja del reino era que no tenía conocimiento del cargo y data de las cuentas de millones, “...ni en qué se convertía el caudal...". El fiscal lo niega, pues la razón de los servicios, y lo que se libraba, corría por despachos de la Sala de Millones, tomada la razón en sus Contadurías ${ }^{19}$, y las cuentas por sus contadores, sin intervención del Consejo de Hacienda, “...y sin el mal cobro que tenían antes de la agregación, y que se formasen mesas en la Contaduría Mayor, para tomar las cuentas de este caudal". Por tanto, la forma de tomar las cuentas fue una razón añadida a las que llevaron a la agregación en 1658. La quinta queja era que la Contaduría Mayor despachaba provisiones llamando a dar estas cuentas. El fiscal defiende que ello es conforme a los acuerdos del reino - su nombre sigue legitimando-, y órdenes de su majestad. La conexión y el ascendiente de la Contaduría era un hecho. La sexta queja era que el Consejo de Hacienda se introducía en la

17. "Acuerdo que el reino hizo en 27 de marzo de $1658 \ldots$.., ff. $6 \mathrm{v}-7 \mathrm{r}$.

18. Francisco, Gabriel Mestre, "Por el reino y don Gonzalo de Aponte y Chaves, su agente y procurador general, cuyo derecho coadyuva y defiende el señor fiscal del Consejo con los fiscales del Consejo de Hacienda y Junta de Millones, sobre que la Junta y Comisión de Millones se reduzca al Consejo de Castilla y corra en la conformidad que tenía al tiempo que se despachó la real cédula de 20 de marzo de 1647", [1675?], Real Academia de la Historia (en adelante RAH), 14/11560(11).

19. Tomar la razón es: "Acreditar, y hacer buena la cantidad pagada, por la ciudad, villa, lugar, o ramo en la renta, paga, y año porque diere satisfacción, y hacer cargo de ella a quien la recibió", Barbero Teniente, Luz y claridad, 2. 
administración, circunstancia que niega el fiscal. También niega la séptima queja en cuanto a que no se consultaban los administradores generales por la Sala. En este punto el reino hacía ver que la administración no se había entregado a los justicias y comisarios, condición con la que se consintió la agregación. Tomás Jiménez Pantoja en cambio defiende que ahora había menos superintendentes que cuando la Comisión estaba en el Consejo de Castilla. Para el reino esas quejas apuntan a la necesidad de que la administración no arrebate aquel "ejercicio" que reivindicaba Francisco Gabriel Mestre. En cuanto a qué forma de administración de las dos es más conveniente, afirma que “...es cuestión tan problemática, como melancólica: díganlo la diversidad de dictámenes, que en todos tiempos ha habido, y la variedad de decretos". Si esa era la realidad, no por ello deja de pronunciarse a favor de los administradores, como muy especiales agricultores, experimentados y diestros, "y sin estas circunstancias, más servirán de esponja de la sangre de los vasallos, que de fruto al servicio de su majestad y al de la utilidad pública". La administración, esa nueva forma de Hacienda, encarna la utilidad y el beneficio, unifica, ordena y vertebra, frente a la iurisdictio, a la misma justicia. La queja nona hacía referencia al presidente de Hacienda, pues con una orden suya y cédula de aprobación, se libraban y pagaban los servicios de millones. Tomás Jiménez en lugar de negar ese poder superior del presidente, resalta su dignidad, autorizada por emperadores como Honorio y Teodosio, a lo que añade la grande autoridad que necesita, la estrecha comunicación que tiene con el rey, "...y el lugar superior que alcanza en su grandeza..."; además de tener "...el mayor imperio después de la majestad", y estar extendida la jurisdicción amplia de este puesto, "Y los motivos de que esta jurisdicción, y potestad de los señores presidentes de Hacienda, sean tan absolutas, como indispensables, no necesitan de más comprobación, que la que enseña la experiencia". Si hay extensión, hay invasión y despojo jurisdiccional, y si también hay grande autoridad, y potestad absoluta, la que elude solemnidades, como la de formar Consejo, se está dando prioridad a las "ocurrencias ejecutivas". Se elude el derecho para dar paso a una ejecución administrativa independiente, suelta, que emana del presidente, y que se hace a sí misma. Finaliza el fiscal alegando los males que había cuando la Sala estaba en el Consejo de Castilla, y añadiendo que con la separación,

...a este gobierno económico le faltarán aquellos ministros, que por el mucho tiempo que ha que tratan estas materias, y el particular cuidado, y estudios que han aplicado, se hallan enterados, y noticiosos de ellas, y de todas las provincias del reino, y sujetos que sirven debajo de su mano; reparo que le hacen todos los buenos políticos, y nosotros no podemos omitirle; pues aunque los señores ministros del Consejo lo tienen todo tan presente, creemos también, que nada tienen tan olvidado como estas económicas disposiciones de Hacienda. 
De nuevo la "mayor inteligencia" y el "mejor expediente". A ello se añade el cumplimiento de las exigencias del "gobierno económico", y las óptimas disposiciones económicas de Hacienda. Se prescinde del ius. Si escondía la potestad absoluta del rey, por su significado negativo en el reino, su insistencia en la "potestad económica", como lo hicieron otros ministros, nos confirma que fue ella el sistema de referencia conceptual confesado de la reforma administrativa de la hacienda. Quitarle al cuerpo místico del Consejo de Hacienda y a su presidente, que incluye, afirma Tomás Jiménez Pantoja, la comunicación de tribunal a tribunal, de ministro a ministro, de renta a renta, de consignación a consignación, de asentista a asentista, de arrendamiento a arrendamiento, de intereses a intereses, con ello no se corta al tribunal,

que si se desuniese esta Sala de aquel Consejo, no solo zozobran la mejor expedición, y más breve despacho de los negocios, en el servicio de su majestad, y beneficio de sus vasallos, sino era quitarle al cuerpo místico de aquel Consejo, y de su presidencia, no sé si digamos, el brazo derecho, por ser el más pujante, y más pronto; y este no se corta al tribunal, sino a la utilidad pública, al real servicio, a la defensa del reino, y a su más seguro gobierno.

La eficacia recaudatoria, y salvaguardar el negocio fiscal, son los pilares que sostienen la agregación. Cuerpo místico, mayor imperio del presidente, potestad regular — que es absoluta—, y "potestad económica" — la que no tiene ius-, brazo diestro de un rey que está sobre la ley y el derecho, se honestan con el principio salus populi suprema lex est. Hay potestad extraordinaria y hay ley suprema que no reconoce la ley del reino. Para Hacienda la agregación desata la representación y voz del regnum, el auxilium de un servicio pactado que obliga a un rey sujeto a derecho, el que es ordinario, a su desobligación como principio constitutivo de la monarquía. Todavía, el 4 de septiembre de 1691, la Diputación en una consulta solicitaría que la Comisión volviese al Consejo de Castilla ${ }^{20}$.

Por tanto, durante el reinado de Carlos II la agregación de la Sala de Millones al Consejo de Hacienda no había dejado de suscitar oposición. Es así como el conflicto legal y político que la nueva situación de 1658 planteaba, no quedó aquí, pues vuelve a plantearse un pleito, esta vez no directamente sobre la agregación, sino sobre sus términos, lo que implicaba un nuevo intento de recuperar a la Comisión o Sala como institución del reino.

20. Fortea, "Trayectoria de la Diputación de Cortes", 82. 


\section{LAS CUENTAS DEL REINO}

En 1681 tuvo lugar un pleito entre el fiscal, agente procurador del reino, y el fiscal de Hacienda y Contaduría, en el que interviene un alcance de millones, con el que se dirime la observancia de las condiciones del servicio, con motivo de un conflicto que se produjo en Medina del Campo ${ }^{21}$. Tenía lugar este conflicto cuando todavía no se había producido la sentencia definitiva del pleito de 1663, que se daría el 21 de febrero de $1682^{22}$. Ello le da a este nuevo pleito un significado político añadido, pues se enmarca en el mismo objetivo de recuperar a la Comisión como institución del reino. Según figura en una provisión, de 26 de noviembre de 1680, dirigida a Diego Colón de Larreátegui, alcalde del crimen de la Chancillería de Valladolid, se le habían dado órdenes y despachos para la cobranza de diferentes maravedíes, trigo y cebada que debían a la real hacienda Jerónimo de San Martín y Carlos de Santamaría, vecinos de la villa de Medina del Campo. Ante las dificultades con las que se encontró, se le mandó despachase audiencia en la forma ordinaria para que procediese a la averiguación y castigo de los excesos, “....y hacer pago a mi real hacienda de lo que justamente estuviesen debiendo los dichos Jerónimo de San Martín y Carlos de Santamaría...". Nombró el alcalde del crimen a Francisco González Mateo, con escribano y alguacil, para que procediese a la averiguación y castigo. Hizo diligencias y autos, sin embargo Francisco Fernández Almejún, alcalde mayor de la villa, con motivo de tener una carta y provisión despachada por el Consejo de Hacienda, en Sala de Millones, ganada a pedimiento de Carlos de Santamaría, le embarazó dicha averiguación y castigo "...y hacer el pago de lo que se está debiendo por los susodichos a mi real hacienda...". Visto por su fiscal todos los papeles generados en la Contaduría Mayor de Cuentas, se formó competencia con el Consejo de Hacienda, en Sala de Millones. El gobernador de Hacienda, Carlos Herrera Ramírez de Arellano, declaró que esta dependencia tocaba a la Contaduría Mayor de Cuentas. Con este motivo se daba la carta a Diego de Colón para que, sin embargo de lo que se proveyese por la Sala de Millones, cumpliese una provisión, de 20 de agosto, despachando la misma audiencia u otros ministros, para que averiguase y castigase los excesos, procediese a la cobranza de los maravedíes y granos que debían tanto Jerónimo de San Martín como Carlos de Santamaría, “....procediendo en todo conforme a derecho y como convenga al mejor cobro de mi real hacienda...". En este encargo estaba el derecho, pero para ponerlo al servicio de la conveniencia del fisco. Se autorizaba el ensanche del ius. Se mandaba asimismo al corregidor de Medina del Campo

21. AHN, Consejos, leg. 28.114.

22. Luis María García-Badell Arias, "La sucesión de Carlos II y las Cortes de Castilla," Cuadernos de Historia del Derecho, no 13 (2006): 131. Fortea, Las Cortes de Castilla, 341-342.

Chronica Nova, 46, 2020, 177-212 - http://doi.org/10.30827/cnova.v0i46.6644 
y a su lugarteniente "...no embaracen a la audiencia que despacharéis, su uso y ejercicio...". Es decir, se le insta a que no acuda al derecho para desobedecer.

En una consulta, de 4 de febrero de 1681, menciona el corregidor que había sido requerido por una provisión real de la Sala de Millones, a pedimiento de Carlos de Santamaría Sierralta,

...recoger los autos hechos por una audiencia que con comisión del licenciado don Diego Colón de Larreátegui, caballero de la orden de Santiago, vuestro alcalde del crimen de la Real Chancillería de Valladolid, está en esta villa contra la persona y bienes del susodicho, y que se desembargue los que hubiere embargados suyos y de otros, y suelte a los que estuvieren presos...

El caso era que,

...la comisión despachada por el dicho don Diego Colón fue en virtud de otra real provisión librada por el vuestro tribunal de la Contaduría Mayor de Cuentas en que expresa tuvo competencia con el dicho vuestro Consejo en Sala de Millones, y haberse determinado tocar el conocimiento de la causa al dicho tribunal...

Una ambivalencia legal que no era un caso insólito. El corregidor, como ocurrió otras veces, finaliza la consulta, "Suplica a V.M. se sirva en su vista de ordenarle lo que debe ejecutar...". Se daba el caso de que todo ello ocurría al interior de una misma institución enfrentando a sus tribunales, lo cual desbarataba su trabazón y unión, la necesaria para que la ley fiscal, desprovista de interpretación contraria, al menos desde sus instancias, pudiese ser vinculante.

Por decreto, de 7 de febrero, se ordena llevar los papeles al fiscal de la propia Sala de Millones. Al día siguiente da su parecer, argumentando que es siniestra la relación según la cual se había formado y vencido la competencia. Se intenta demostrar que hay obrepción, porque ella faculta la desobediencia, con la representación jurídica que aporta una mayor información en derecho, que esta vez se pone al servicio de la Sala de Millones. A ello añade el fiscal,

...el Consejo de Hacienda en Sala de Millones es tribunal supremo con la misma autoridad y regalía con que se hallaba en el de Castilla, y le está concedida la absoluta administración y cobranza así en lo principal como en mandar tomar las cuentas, decidir las dudas y cobrar los alcances, sin que la Contaduría Mayor por título alguno, ni legal, ni real, tenga jurisdicción en esta administración, decisión de dudas, ni llamamiento a cuentas, ni cobranza de alcances, porque este caudal es concesión del reino a su majestad, y no procede de tributos, ni regalías nacidas ni agregadas a la real corona, como todo se califica por las condiciones de millones, ordenanzas, y autos para restablecer su observancia...

Las condiciones de millones, y con ellas la legalidad del reino, son el sistema de referencia de la "absoluta administración" y condición suprema de la 
Sala, con su separación de los tribunales de Hacienda. El acuerdo de agregación recogía que formaría Sala separada, diferente de las demás, para las materias de millones y demás servicios que ella administraba, “...con la misma autoridad, y jurisdicción suprema que tienen las demás Salas de aquel Consejo [de Hacienda], y que su majestad tiene dada a la Comisión de Millones..." 23. Conservaba la Comisión su estatus de tribunal supremo, en correspondencia con los demás tribunales de Hacienda; también en correspondencia con otros tribunales del reino, pues la Diputación tenía el tratamiento de tribunal supremo ${ }^{24}$. El reino no podía ser subordinado, pero tampoco subordinar. La Audiencia de la Contaduría Mayor era tribunal supremo en materia de rentas ${ }^{25}$. La Contaduría Mayor, nos dice el contador Martín de San Martín Ocina, cuando los Reyes Católicos crearon los cuatro contadores de cuentas, "...entendieron con jurisdicción absoluta en hacer llamar, y tomar cuentas..." ${ }^{26}$. Menciona Tomás de Aguilar, quien en 1640 era contador de cuentas de la Contaduría Mayor, “...la trabazón y correspondencia que tienen entre sí los tres tribunales de Hacienda, y los contadores oficiales que militan debajo de su gobierno...", y apunta que, durante el reinado de Felipe III, por unas ordenanzas, de 26 de octubre de 1602, “...se dispuso que el Consejo de Hacienda y la Contaduría Mayor de ella fuese todo un tribunal, como ahora lo es, y que se llama Consejo de Hacienda y la Contaduría Mayor de ella"27. Ello no impide a Juan del Castillo Sotomayor, oidor de la Contaduría Mayor de $\mathrm{Cuentas}^{28}$, defender con respecto a ambos tribunales,

....que siendo en la sustancia y en el efecto los tribunales distintos y separados, aunque se gobiernan con un mismo presidente, y un mismo nombre de Consejo

23. "Acuerdo que el reino hizo en 27 de marzo de 1658...".

24. Castellano, Las Cortes de Castilla, 103.

25. José Luis de las Heras, "La jurisdicción del Consejo de Hacienda en tiempos de los Austrias," en Estado y fiscalidad en el antiguo régimen, Actas del l Simposium Internacional: Estado y Fiscalidad en el Antiguo Régimen, ed. Carmen María Cremades Griñán (Murcia: Universidad de Murcia, 1989), 121-122.

26. "Discurso y representación del fiscal del tribunal de la Contaduría Mayor de Cuentas... sobre los consumos de libranzas inciertas de asentistas y hombres de negocios, para su instrucción”, [posterior a 24 de octubre de 1673], BN, Porcones, 255(3), ff. 10v-11r.

27. "Relación del estilo de los contadores del Consejo de Hacienda, Contaduría Mayor", [1641], BN, Mss $18731 / 5$, f. 2r. La autoría de este papel aparece en una anotación aparte. En el discurso se presenta como contador del donativo voluntario de 1625 , que podemos confirmar con otro documento, pues a Tomás de Aguilar lo encontramos como contador en una cédula de 6 de noviembre de 1626, con motivo de los arbitrios que debían llevarse a la Junta del Donativo, AHN, Consejos, leg. 40.611.

28. Así lo encontramos en 1629, también como juez privativo de la Junta del Donativo de 1625, en una carta de comisión, de 2 de mayo de 1629, AHN, Consejos, 28.057. Como tal sigue apareciendo en 1633, "Por la ciudad de Guadalajara con Jerónimo de Vitoria y consortes vecinos de la villa de Alcalá...” (Madrid, 1633), BN, Porcones, 1175(1). 
de Hacienda, y haberlos distinguido y separado las mismas leyes y ordenanzas reales... ${ }^{29}$.

La separación de la sustancia y el efecto preponderan a la unión del nombre. El argumento vale también para la Sala de Millones, no obstante que en ella, desde 1639, y como fuera ratificado en 1658, pudiese asistir también el presidente de Hacienda. Para el fiscal la agregación, de 27 de marzo de 1658, no conllevaba ni subordinación ni fusión, sino confirmación de una autoridad independiente, el componente de cualquier auctoritas dotada de iurisdictio en el siglo XVII; por tanto, en correspondencia con cualquier otro tribunal, lo menciona el propio contador Juan del Castillo ${ }^{30}$. Ello con su sistema de referencia legal privativo, que servía para diferenciarse de los tribunales del Consejo de Hacienda. Martín de San Martín Ocina, en un discurso, menciona la confusión jurisdiccional de la que se servían las partes acudiendo al Consejo de Hacienda con relaciones siniestras, denuncia “...y no mezcle la codicia de las partes ambas jurisdicciones por sus particulares fines en perjuicio del cobro de la real hacienda" ${ }^{31}$. Termina el discurso diciendo se debía advertir al Consejo de Hacienda y a la Sala de Millones “...para el mejor expediente de los negocios de la Contaduría Mayor en orden a excusar los embarazos, de que se valen las partes para sus intentos..." 32 . Las garantías legales que ofrecía la iurisdictio, que actuaba según el principio de diversidad judicial, una garantía esencial del derecho, cuya jurisdicción privativa no inhibe absolutamente, negando el recurso, estaba al interior de los tribunales de Hacienda. En la independencia, acompañada de la soberanía de la iurisdictio de cada tribunal, frente a la mezcolanza interesada, está para Martín de San Martín Ocina el mejor cobro, cuenta y razón del fisco.

Recoge este contador que la agregación, de 2 de febrero de 1659, a la Contaduría Mayor de Cuentas de los servicios, sisas y demás impuestos concedidos por el reino, se produjo,

29. "El argumento de este papel es mostrar y fundar brevemente, que el tribunal y Consejo de los señores oidores de Hacienda, y Contaduría Mayor de su majestad, tienen en algunos casos jurisdicción privativamente..." (la BN data su publicación en 16--?), BN, VE, 209/78, f. 5r.

30. Refiriéndose a la separación entre la Contaduría, su tribunal de oidores, frente a los ministros de capa y espada del Consejo de Hacienda, "Y como la Chancillería de Valladolid no se puede entremeter en los pleitos y negocios que tocan a la de Granada et versa vice, ni uno de los Consejos de Madrid en lo que toca a los otros, porque se diera grande confusión, y resultaran grandes inconvenientes. Lo mismo se ha de observar y guardar en los dichos dos Consejos y tribunales, porque por las dichas leyes reales está distinguida y separada la jurisdicción y conocimiento de pleitos y negocios, y dada a cada uno la suya privativamente, y se siguieran los mismos inconvenientes, y confusión, y daño de los litigantes, que en los Consejos y Chancillerías", "El argumento de este papel es mostrar y fundar brevemente...", f. $5 \mathrm{v}$.

31. "Discurso y representación", f. 4r.

32. "Discurso y representación", f. 16v. 
...con la misma jurisdicción, ordenanzas, y estilo que corresponde a las rentas reales, que se administran por el Consejo de Hacienda, con libros distintos y separados, y correspondientes a la administración que corre por la Sala de Millones, y en las materias del tribunal de la Contaduría Mayor, no tiene dependencia, asistencia, ni parte ninguno de los dos fiscales del Consejo de Hacienda, y tribunal de los señores oidores, y solamente toca al de la Contaduría Mayor, cuanto se causa, ajusta y fenece en la Contaduría de Millones, en ejecución de las ordenanzas, y estilos que se gobierna ${ }^{33}$.

El Consejo de Hacienda no podía intervenir, pero la independencia de la Contaduría de Millones pasaba por su dependencia de la Contaduría Mayor. La Contaduría de Millones no desaparecía, pues estaba compuesta de cinco mesas, con diez contadores de resultas. Por muy amplia que sea la jurisdicción de un tribunal —ese era el caso del Consejo de Hacienda—, “....no se puede entremeter en las causas que especialmente están cometidas a otro" 34 , aunque ese otro forme parte del mismo Consejo. La agregación era entremeterse. Como consecuencia, considera el fiscal en su parecer, de 8 de febrero, que todo lo ejecutado por la Contaduría es "...contra su real palabra y juramento, perturbando el orden de las jurisdicciones tan contra su mejor servicio y beneficio de sus vasallos...". El orden jurisdiccional, su amojonamiento y soberanía, concernía — como era el caso de la Contaduría Mayor- también a la Sala de Millones, que en este caso llamaba al juramento y palabra del rey, a una legalidad constituida que unía el servicio a la majestad con el servicio a los súbditos. Es decir: esta vez se hacía gala de que la conveniencia de la hacienda se reconciliaba con un beneficio común, cuya custodia era el cometido de cualquier iurisdictio, pero que ahora indicaba a una hacienda que no expoliaba a los vasallos, sino que velaba también por su bienestar. Si había conveniencia de la real hacienda, había también justicia, la necesaria para que un tributo pudiese tomar ser. La independencia jurisdiccional no era nueva, sino que se correspondía con su situación anterior, cuando formaba parte del Consejo de Castilla, cuando era Comisión y tribunal supremo, circunstancia que la incorporación a Hacienda no anuló, representada en este momento por aquella "absoluta administración"; es decir, completa, perfecta, sin carencias, los componentes necesarios de cualquier tribunal supremo. Pide que en la Sala se vean todos los autos, con cuya vista protesta alegar lo que convenga, y “...se represente a sus majestades el injusto despojo de jurisdicción que la Contaduría Mayor introduce contra este Consejo, cómo se le usurpa, y caudal que le toca". Con este caudal se pretende mantener la distinción jurídica entre la hacienda del rey y la hacienda del reino, con sus implicaciones, no solo contables, sino asimismo legales, y las propias de una relación contractual de servicio al rey.

33. "Discurso y representación", f. 5v.

34. Castillo Sotomayor, "El argumento de este papel es mostrar y fundar brevemente...", f. 6r.

Chronica Nova, 46, 2020, 177-212 - http://doi.org/10.30827/cnova.v0i46.6644 
Por una carta de Carlos II, de 12 de febrero, alude el rey que el corregidor, Manuel Antonio de Quiñones Pimentel, tenía personas presas a las que se les habían embargado sus bienes, asimismo había sacado multas, todo en virtud de órdenes de la Contaduría Mayor de Cuentas. Pero se le había ordenado por una carta y provisión, de 27 de enero, suspender y recoger “...cualesquiera despachos de poder, de cualquier persona, y los remitieseis originales ante los de la dicha Sala de Millones...”. El corregidor no le había dado cumplimiento, alegando que había sido requerido con otra provisión de aquel tribunal. Visto todo por la Sala de Millones, recuerda,

...que el tribunal ni otro ningún Consejo, Audiencia, ni Chancillería, se puede entrometer en lo tocante a la administración, beneficio y cobranza de los dichos servicios, por estar como están todos inhibidos de su conocimiento, por diferentes cédulas y despachos nuestros...

Con el acuerdo de la Sala, se le ordenaba cumpliese la carta de enero. En el momento de su notificación, el 15 de febrero, mostró al escribano una carta firmada por el presidente de Hacienda, Carlos de Herrera,

...en que le ordena recogiese cualesquier despachos que viniesen de los señores del Consejo de Hacienda de su majestad en Sala de Millones, en razón de lo que contiene esta dicha real provisión, y que en virtud de ella recogía dichas reales provisiones, y con efecto se quedó con ellas dicho señor corregidor...

Las diferencias entre la Sala y su presidente, no quedaban en la corte, daban lugar a diferentes sistemas de referencia legal que concernían a las ciudades y a su corregidor.

En una carta, de 16 de febrero, que Diego Santos, residente en Medina del Campo, escribe a Carlos de Santamaría Sierralta — cuyos bienes tenía rematados por deudos a la real hacienda-, menciona que “...el corregidor ha dicho públicamente que aunque vengan más provisiones que hay estrellas no les ha de dar el cumplimiento, y las ha de recoger, siendo de los señores de la Sala de Millones...". Aquí mostraba el corregidor su oposición frontal al administrador de millones, como era habitual sucediese con motivo de la reforma administrativa de la hacienda. El propio Carlos de Santamaría hace ver en una súplica los perjuicios que le acarreaban el incumplimiento del corregidor, añadiendo, “... demás de ser esto punto de jurisdicción...". Este punto llamaba a la diversidad de sistemas de referencia legal custodiados por los distintos tribunales, como en tantos conflictos de competencias, pero con la diferencia de que ahora se situaban en el centro del Consejo de Hacienda, sus salas y tribunales, teniendo como fondo el servicio de millones. Por tanto, la incorporación de la Comisión a Hacienda no impidió que ese punto de jurisdicción dejase de plantearse, y ser motivo de conflictos, que al producirse en su interior, venía a confirmarlos en 
otros ámbitos, con la contravención que los acompañaba; y que las condiciones de millones no solo no perdiesen su valor político, sino que su cumplimiento o incumplimiento continuase siendo un dilema legal sujeto a interpretación, incluso desde donde debían ser consideradas como un principio absoluto. Ese "punto de jurisdicción" no era específico de la Sala de Millones, por su bagaje legal como representante del reino, pues hemos visto que un contador defendía el mismo "punto" para la Contaduría Mayor de Hacienda. Por tanto, no era solo el reino el motivo de disputa, sino la iurisdictio que lo respaldaba, porque ella era la hacedora de la separación e independencia de cada sistema de referencia legal, con las diferentes alternativas de ejecución que aportaba.

El 4 de marzo, el agente del reino, Gonzalo de Aponte y Chaves, en una súplica elevada a la Sala de Mil y Quinientas del Consejo de Castilla, recuerda que ella tiene la jurisdicción con inhibición para que conozca sobre la observancia y cumplimiento de las condiciones de millones en caso de contravención. Mientras que, continúa, a la Sala de Millones está concedida la jurisdicción privativa con la misma inhibición, y que la incorporación de 1658, “...fue con calidad de conservar la misma jurisdicción, preeminencias y prerrogativas que tenía...". Es decir: sigue siendo Comisión, antes que Sala dependiente, su condición de tribunal supremo no ha desaparecido. Así, lo que había sucedido es que la Contaduría Mayor de Cuentas,

...ha procurado extender su jurisdicción y entrarse a tomar conocimiento en las causas que privativamente tocan a la dicha Comisión de Millones, oponiéndose a sus contratos, capítulos y cédulas reales de su aprobación, particularmente habiendo dado su cuenta en la Contaduría Mayor y en la mesa de contadores de resultas de millones, Domingo González de Villegas, depositario del servicio de quiebras, y reparándosele una partida de 525 mil maravedíes...

La partida correspondía a una letra que Carlos de Santamaría Sierralta había dado a favor de Sebastián Cortizos, portugués, y Andrea Piquinoti, genovés ${ }^{35}$, cuyas firmas venían actuando asociadas ${ }^{36}$. Había sido el administrador de millones, Álvaro Gallo, quien había dado a Carlos de Santamaría el libramiento. Afirma el agente, que Carlos de Santamaría “....acudió a la Sala de Millones del reino, $\mathrm{y}$ en contradictorio juicio, habiendo justificado su paga, obtuvo autos de vista y

35 Manuel Garzón Pareja, La hacienda de Carlos II (Madrid: Instituto de Estudios Fiscales, 1981), 170.

36. Véase Carmen Sanz Ayán, "Presencia y fortuna de los hombres de negocios genoveses durante la crisis hispana de 1640," Hispania, LXV, no 219 (2005): 106. Sanz Sayán, “Consolidación y destrucción de patrimonios financieros en la edad moderna: los Cortizos (1630-1715)," en Fortuna y negocios: formación y gestión de los grandes patrimonios (siglos XVI-XX), Coord. por Ricardo Robledo Hernández e Hilario Casado Alonso (Valladolid: Universidad de Valladolid, 2002), 73-98.

Chronica Nova, 46, 2020, 177-212 - http://doi.org/10.30827/cnova.v0i46.6644 
revista para que se le hiciese buena: y acudiendo con el despacho que se le dio para este fin a la Contaduría”. Entonces fue cuando dio orden para que Diego de Colón de Larreátegui pusiese cobro a dicha partida. El repartimiento general del servicio de quiebra de millones había cesado en 1669, pero, en 1673, en algunas ciudades se volvió a usar de los medios antiguos para su satisfacción. El objetivo de este servicio fue precisamente, además de acudir a una serie de gastos como Casa Real, armadas, presidios, nóminas de los Consejos, para que los hombres de negocios pudiesen cobrar $^{37}$. En 1637 se había establecido que su administración y cobranza corriese enteramente por Hacienda ${ }^{38}$. Ahora se introducía la consignación de su deuda en el sistema de referencia legal del reino, que era aprovechado para contradecir a la Contaduría Mayor.

Consideraba el agente que se estaban quebrantando las condiciones y capítulos de millones, y suplicaba que

...en cualquier estado que se hallare el caudal de ellas, aunque sea en juicio de cuentas y ejecución de ellas y de sus alcances, privativamente toca a la Sala de Millones del, con inhibición al dicho tribunal de la dicha Contaduría Mayor de Cuentas, y a los demás Consejos, audiencias y tribunales en la misma forma y con la propia jurisdicción y prerrogativas que estaba en el Consejo Real de Castilla; respecto de haber pasado con ellas al de Hacienda, y en caso necesario le mande no se entrometa en ella ni otra de esta calidad, en ejecución y cumplimiento de los dichos capítulos y condiciones de millones, y que den cumplimiento a cualesquier determinaciones y despachos que se dieren por la dicha Sala en orden a lo referido...

El agente del reino quiere hacer valer una incorporación al Consejo de Hacienda sin consecuencias jurisdiccionales. La Contaduría Mayor es un tribunal foráneo, como cualquier otro que no pertenezca a Hacienda. Luego la Contaduría estaba defendiendo y poniendo en práctica lo contrario, como consecuencia de las reformas del reinado de Felipe IV, la dependencia de la Sala en materia de cuentas con ella. Pero, para el agente del reino con aquella exterioridad la Comisión continúa disfrutando de soberanía, su jurisdicción sigue siendo "plena y absoluta", sin mermas ni dependencias, como la que disfrutaba cualquier otro tribunal supremo.

En materia de cuentas estaba en juego la situación de la deuda, la independencia contable debía ser una realidad para conservar su control, con su apremio, determinación y prelación. En esta prelación podían intervenir tanto razones políticas de servicio, como por otra parte religiosas. Una de estas últimas lo era,

37. Jerónimo de la Carrera Portocarrero, "Resumen general de las rentas reales que son afectas a la contribución en estos reinos de Castilla y León..." (Madrid, 22 de noviembre de 1681), BN, Porcones, 70/28, ff. 2r-2v.

38. Fernández Albaladejo, "La resistencia en las Cortes", 345. 
por ejemplo, el cuidado de las ánimas del Purgatorio, cuya reserva obligaba al Consejo y Contaduría Mayor de Hacienda ${ }^{39}$. Prelación que suplicará el reino, el 19 de mayo de 1662, frente al propio Andrea Piquinoti ${ }^{40}$. La "mayor conveniencia" — su "ley tiránica"-, de Tomás Jiménez, lo era para la propia hacienda, pues muchas veces, lo dice Felipe IV, en cédula de 18 de julio de 1648, había sido la necesidad la que concertó asientos "...capitulando algunas cosas que causaban reparo, por ser en perjuicio de mi real hacienda" ${ }^{41}$. Afirmación que se repite en una cédula, de 14 de agosto de 1662, con motivo de otra suspensión de pagos, precisando esta vez "en perjuicio conocido de mi real hacienda", pues era justo que se hiciesen contratos de esta calidad proporcionados “...con la razón, y con la justicia...". Una política de reservas que continúa durante los primeros años del reinado de Carlos II ${ }^{42}$. No obstante el apremio, con su mal, aquella necessitas se tenía que debatir con otras leyes y con el derecho desde las instancias de los tribunales de Hacienda. El hecho de que se produjese entre sus tribunales no era contradictorio. Nos dice el contador Alonso Barbero, a la pregunta de "¿cómo se debe gobernar el contador en la distribución de juros y libranzas?", responde “Arreglándose a las órdenes de su majestad, y señores de su Real Consejo de Hacienda, en que está mandado, y prevenido se dé satisfacción a los interesados, en su grado, y lugar, sin posponer al anterior en su paga" ${ }^{43}$. Cada acreedor tiene señalado un lugar y se le debe guardar en los partidos. Por auto, de 13 de enero de 1645 , precisa el rey, competía solo a los administradores generales, justicias y comisarios de millones, no a los contadores, la disposición de las pagas de las consignaciones y libranzas ${ }^{44}$. Pero en el camino de su satisfacción estaba la desobediencia jurídica, la misma que caracterizaba la comunicación entre cada iurisdictio, al interior del Consejo de Hacienda, cuyos miembros se comportan en sus relaciones mutuas como los demás tribunales en Castilla. La desobligación del derecho era una cuestión que también concernía a Hacienda, al apremio de la satisfacción de la deuda, pues en esa satisfacción no solo intervenía su imperiosidad, las razones del reino tenían cabida. Su control mantenía divididos a los

39. Ese es el caso, por ejemplo, de la reserva de juros que pertenecían a capellanías y obras pías, cuyos réditos se distribuían en misas y sufragios, “...por consistir en ellos el mayor alivio de sus penas, y gozar con más brevedad de la bienaventuranza", Cédula Real fechada en Madrid, octubre de 1661, dirigida al gobernador, Consejo y Contaduría Mayor de Hacienda, BN, VE, 211/28. Véase Sanz Ayán, "La evolución de los juros durante el reinado de Carlos II," en La decadencia de la monarquía hispánica en el siglo XVII. Viejas imágenes y nuevas aportaciones, ed. María del Carmen Saavedra (Madrid: Editorial Biblioteca Nueva, 2016), 157-159.

40. Actas de las Cortes de Castilla (en adelante ACC) (Madrid: Real Academia de la Historia, 2000), 61,II:248.

41. BN, VE, 199/2.

42. Sanz Ayán, "La evolución de los juros", 161.

43. Barbero Teniente, Luz y claridad, 4.

44. BN, VE, 195/13.

Chronica Nova, 46, 2020, 177-212 - http://doi.org/10.30827/cnova.v0i46.6644 
tribunales en diferentes sistemas de referencia legal. La desobediencia jurídica seguía siendo posible.

Juan de León, fiscal de la Contaduría Mayor de Cuentas, eleva también una súplica a la Sala de Mil y Quinientas del Consejo, el 18 de abril del mismo año de 1681. Hace ver el fiscal lo que el agente del reino alegaba en cuanto a que la deuda de Carlos de Santamaría procedía de quiebra de millones, y que ésta, como otras causas de millones, aunque fuesen de ajuste de cuentas, tocaba su conocimiento a la Comisión. Juan de León, responde defendiendo que,

...ésta se debe seguir y sustanciar con el fiscal del Consejo de Hacienda, con quien hace un cuerpo el dicho tribunal, por ser punto de derecho, que se ha de ventilar en justicia, y ser de capa y espada el fiscal del tribunal, por cuya razón y motivo dispone la ordenanza que las causas de justicia del, las siga y defienda el fiscal del Consejo de Hacienda, y así se ejecuta en todas.

El fiscal de la Contaduría expone una cuestión jurídica, no reconociendo a la Comisión como tribunal supremo e independiente. La agregación de 1658 ha tenido consecuencias jurisdiccionales, la Comisión se había transformado, se había hecho cuerpo con el Consejo de Hacienda. Había fusión jurisdiccional, no amojonamiento al interior de este Consejo. La Comisión independiente como tal ya no existe, ahora es una dependencia de Hacienda. La integración disuelve la soberanía. Sin esta última en la Sala no hay representación de un reino que es soberano. El Consejo de Hacienda es, no la Comisión, el tribunal que tiene la supremacía.

El fiscal del Consejo de Hacienda, Esteban Fermín de Marichalar, a quien se había remitido la demanda del agente del reino, en súplica de 29 de abril, defiende que ella se había hecho con obrepción, también a él podía serle útil la desobligación. A pesar de los argumentos del fiscal de la Contaduría, sí hay amojonamiento entre los tribunales de Hacienda. Niega que la deuda de Carlos de Santamaría proceda de cuenta de quiebra de millones. Aun en este caso, precisa,

...y porque aunque el proceder contra el dicho Carlos de Santamaría fuese por cobranza de renta de millones, cuya cantidad procediese de alcance de cuenta que estuviese dado en la Contaduría Mayor, tocaba y toca al dicho tribunal el conocimiento, y de todos los demás alcances y dependencia de cuentas, y llamar a ellas, y en esta posesión ha estado y está desde el año de $1659 \ldots$

Se trataba de la cédula de 2 de febrero de $1659^{45}$. Con la primera concesión del servicio de millones en 1590 , fueron los contadores de rentas, quitaciones,

45. La cédula establecía: “..., por la presente mando que la superintendencia de las dichas cuentas de millones se agregue al tribunal de Cuentas de mi Consejo de Hacienda, por asistir los contadores 
y salvado, quienes tuvieron la cuenta y razón de la cobranza de los primeros 8 millones concedidos por el reino. Por estos contadores se despacharon las receptorías, y demás recaudos para que la cobranza tuviese efecto ${ }^{46}$. Según nos informa el contador Tomás de Aguilar, la confianza de los monarcas en la Contaduría era total,

...es de tanta conveniencia que las cuentas finales se tomen en la Contaduría por la inteligencia y comprobaciones con que se hace que en las ordenanzas del señor rey don Felipe $3^{\circ}$ se dispone y mandar que en cuanto sea posible se excuse enviar a tomar cuentas fuera ${ }^{47}$.

Además, "En estos oficios de contadores de libros, y en las secretarías de Hacienda y en la Contaduría Mayor de Cuentas son los seminarios donde se crían los oficiales diestros, y a propósito para tomar cuentas..." 48 . Antes de la reforma de 1659, según figura en un papel del secretario Juan de Tolosa, de 1635, ya los contadores de la razón de la Contaduría Mayor de Hacienda tomaban la razón de las libranzas que el rey daba en los nuevos millones a asentistas y tesoreros generales, para hacerles cargo de ellas “...y de todos los cargos que de esto hay..." ${ }^{49}$. Se daba el caso de que, por ejemplo, los contadores de penas de cámara, estando subordinados al Consejo Real, se tenían a la vez como contadores de libros del Consejo de Hacienda, y se consultaban por él ${ }^{50}$. Había, por tanto, convivencia de diferentes sistemas de referencia en la contabilidad.

de resultas de millones en la misma Sala del tribunal, para que a las mismas horas del cuide del gobierno y buena expedición de las dichas cuentas de millones...". A ello añadía, "Mando que las cuentas que no pudieren tomar los dichos mis contadores de resultas de millones, por ser muchas, se repartan entre los demás mis contadores de mi Contaduría Mayor de Cuentas, que están sin ejercicio y fuera del número, y que estos vayan entrando en lugar de mis contadores de millones, como fueren vacando".

46. Juan de Tolosa, "Compendio de los despachos que tocan a despacharse en los oficios de los contadores de los libros del Consejo y Contaduría Mayor de Hacienda de su majestad para el gobierno y administración de ella" (Madrid, 20 de julio de 1635), BN, Porcones, 97/28, f. 9v. Véase Francisco Tomás y Valiente, "La Diputación de las Cortes de Castilla (1525-1601)," en Gobierno e instituciones en la España del antiguo régimen (Madrid: Alianza: 1982), 40.

47. Decía el contador, “....aunque los demás Consejos y Juntas que tienen tesoreros y receptores o personas particulares en cuyo poder entra el dinero los piden cuenta por vía de tanteos para tener noticia y sabiduría de lo que para en su poder, y disponer la distribución de ello no los releva de la final, y cuando por el Consejo de Hacienda se dan conminaciones para tomar cuentas por vía de tanteos se previene en ellas que los tanteos después de acabados se entreguen en la Contaduría para que sirvan de luz, y claridad de las cuentas finales...", "Relación del estilo de los contadores del Consejo de Hacienda, Contaduría Mayor...", ff. 21r-21v.

48. "Relación del estilo de los contadores del Consejo de Hacienda, Contaduría Mayor...", f. 19r.

49. Tolosa, "Compendio de los despachos...", f. 2r.

50. Aguilar, "Relación del estilo de los contadores del Consejo de Hacienda, Contaduría Mayor...", f. $19 \mathrm{r}$.

Chronica Nova, 46, 2020, 177-212 - http://doi.org/10.30827/cnova.v0i46.6644 
Mantener la contabilidad del reino en Hacienda era posible. Sin embargo, en 1659, cuando Felipe IV, continuamos con el fiscal,

...se sirvió remitir y agregar al dicho tribunal [Contaduría Mayor de Cuentas] toda la dependencia de cuentas de los servicios de millones y poner cobro en los alcances que de ellas resultasen, por asistir los contadores de millones en la misma sala del tribunal...

La contabilidad deshacía la separación de los tribunales. En su lugar había trabazón institucional marcando un nuevo estatus para la Sala de Millones, que con las cuentas perdía su soberanía con la representación del reino.

Concluye Esteban Fermín,

...y porque reconociendo el gobernador del Consejo de Hacienda los despachos que a un mismo tiempo daban contrarios los dos tribunales, declaró con vista de los autos tocaba el conocimiento al de la Contaduría Mayor en el caso referido del dicho Carlos de Santa María, y estando como están debajo de su gobierno y presidencia no puede dudarse le tocó esta declaración conforme a las leyes y ordenanzas.

Para el fiscal de Hacienda hay una sola voz, con ella una sola probabilidad puede hacerse materia jurídica en los tribunales de Hacienda. Con esa unicidad fiscal amenaza la compulsión que anhelan sus ministros. Esteban Fermín piensa que la agregación disuelve la independencia, hay unidad de acción a partir de un solo gobierno y de una sola dirección, lo había dicho Felipe IV en 1658, “...para que esto sea con la dirección, y gobierno conveniente...”. Las disensiones y divergencias entre sus salas, ministros y tribunales no debían ejercer como garantías jurídicas de los súbditos, pues la agregación que hace un solo cuerpo se integra en un único sistema de referencia legal, con su gobernador a la cabeza. Ello significa que el reino perdería la fuerza de su representación en la Sala, política y legal, la que procede de la idiosincrasia de su hacienda, diferenciada de la del rey. Las leyes y ordenanzas del Consejo de Hacienda son el cuerpo legal que avala una forma de proceder construida sobre la base de la unidad, que debe hacer camino en las ciudades homogeneizando, frente a la supremacía de las condiciones y capítulos de millones, con su alteridad. Y no solo estaban las ordenanzas, pues no hallándose prevenido — no era el caso-, por las ordenanzas del Consejo de Millones, lo dice su fiscal, "(unido ya al de Hacienda) se debiera recurrir a lo que por el estilo, y práctica se observa en dicho Consejo de Hacienda, por ser conforme a derecho" ${ }^{51}$. De nuevo se acude

51. "Por el rey el licenciado don Juan Bautista Muñoz Sáenz Navarrete... fiscal de Hacienda, en Sala de Millones, y el escribano mayor de rentas de dicha Sala con Marcos Antonio de Molina, 
al nombre del derecho, omitiendo la sustancia, la que está en la independencia. Si es tribunal superior, para el fiscal Juan Bautista Muñoz, “...y en quien reside el gobierno universal...", además de "...lo particular del despacho de todas las rentas de millones del reino...", ello no impide pueda haber fusión, cuando la situación lo requiera. Como respuesta a la cédula, de 2 de febrero de 1659 , por un auto de 25 de agosto de 1659, la Sala de Millones había establecido un reparto de tareas ${ }^{52}$, cédula que se incorpora al expediente de 1681 .

El agente del reino, Gonzalo de Aponte y Chaves, el 16 de mayo de este año de 1681, defendiendo que la causa toca privativamente a la Comisión de Millones, así en su origen, como por ser dependiente de la antecedente, que estaba calificado por ejecutoria suya,

Y porque esto mismo se dispone por las ordenanzas de la dicha Comisión de Millones, que están aprobadas por cédula de su majestad de 11 de enero de 1657. Y porque también se concede esta jurisdicción por diferentes cédulas reales expedidas en ejecución de las condiciones y capítulos de millones al tiempo de la concesión de estos servicios, en fuerza de contrato oneroso y recíproco. Y porque la consignación hecha a los hombres de negocios no mira al punto de jurisdicción, sino a la satisfacción y paga, quedando el conocimiento de las causas y controversias que se ofrecieren a la Comisión de Millones, a quien toca.

escribano de millones de esta villa [Madrid]", [posterior a 27 de marzo de 1658], BN, Porcones, $43 / 33$, f. $5 \mathrm{v}$.

52. Dicho auto establecía: “...para que en la inteligencia y práctica de lo que por la dicha real cédula se manda, no se ofrezcan dudas, de que resulte embarazarse los negocios en perjuicio de la real hacienda y de las partes interesadas, declararon que todo aquello que el tribunal platica en las cuentas que tocan a las cuentas de las rentas reales, asientos, provisiones del Consejo de Hacienda, ha de practicar y ejercer en todo lo que tocare a las cuentas de los servicios de millones, diciendo las dudas que se ofrecieren a los contadores en las partidas que repararen o testaren por falta de recados, y en todo lo demás que en la prosecución de las cuentas y de su fenecimiento se ofrecieren y pudiere ofrecer cobranza de alcances, y todo lo demás que de ellas dependiere y resultare, y que siendo necesario despachar ejecutores a la cobranza de los dichos alcances y de los que se impusieren por los llamamientos y ejecutorías y penas se han los despachos por el dicho tribunal con el nombre en blanco, días y salarios para que los llene el señor presidente, correspondiéndose con las personas a quien se encargaren, formándoselos despachos por las mesas a quien tocare, y que todo lo demás que mirare a su pensión o espera de la cobranza de los dichos alcances, rescuentro o composición de ellos de unas cuentas con otras, determinación en las pretensiones que se interpusieren por las partes que hubieren presentado las dichas cuentas, para que se les hagan buenas algunas partidas por vía de salario, ayuda de costa, quince al millar, o por otra cualquier causa, se ha de ver y determinar por el dicho Consejo de Hacienda en Sala de Millones, y no por el tribunal de la dicha Contaduría de Cuentas, y para que se puedan hacer buenas las cantidades que procedieren de resto de las dichas cuentas ha de preceder cédula de su majestad despachada por el dicho Consejo en Sala de Millones...". 
No obstante aquella unión circunstancial, vemos enfrentados dos sistemas de referencia independientes, las leyes y ordenanzas del Consejo de Hacienda, por un lado, las ordenanzas y condiciones de millones, por otro. La agregación de 1658 no puede anular la variedad legal que es consubstancial a la iurisdictio. El fiscal de la Sala de Millones, que entonces era el mismo Tomás Jiménez Pantoja, el 20 de enero de 1681, había defendido que, tratándose de caudal de millones, “...por todos medios se convence estar procediendo sin jurisdicción el tribunal de la Contaduría Mayor...". Un argumento recurrente con motivo de los conflictos de competencias entre distintos tribunales y ministros, que caso de darse tenía fuerza legal, la tiene para quien en 1668 había defendido la subversión y la nueva forma. La diversidad de la iurisdictio, con su independencia, que caracterizaba el orden jurídico de la monarquía, no había cesado en 1658, manteniéndose activa al interior del Consejo de Hacienda. Pero, además, los diferentes referentes legales podían servir para apoyar las posturas enfrentadas. Con la agregación de 1658, la Sala o Comisión de Millones, conservaba intacta su jurisdicción suprema, su soberanía. Con su sistema de referencia legal, la naturaleza pactista del auxilium no había perdido su valor, pues se apela a él para defender las competencias de la Comisión. Ahora se estaba dirimiendo la satisfacción de la deuda de los asentistas y factores, un tema que tradicionalmente había mantenido enfrentados al rey y al reino ${ }^{53}$, con la secular oposición de las ciudades a su satisfacción. Ello no obstante argumentos como el de, además de poner a los hombres de negocios con crédito, “...la conexión, y derivación que tienen unos con otros dominios, con que difundiéndose así el desempeño de su majestad, gozan también del sus vasallos..."; hace referencia Felipe IV a las deudas que tenían estos hombres con los particulares ${ }^{54}$. Su determinación, afectando a cuentas de millones, no escapa al control del reino, que para su agente se mantiene vigente en la Comisión. Gonzalo de Aponte está bregando porque la Sala de Millones conserve sus atributos legales como representante del reino, que no era parva materia, el control de las causas de la deuda no lo era. Lo que significa que la agregación de la Comisión a Hacienda no había destruido los valores de servicio de la hacienda del reino, su idiosincrasia legal.

Responde Gonzalo Chaves,

Y porque la cédula del año de 1659 que en contrario se refiere, no pudo alterar las antecedentes, por ser concedidas al reino por contrato oneroso y recíproco, y de ella no tuvo noticia, y todo lo demás que se refiere, caso negado que sea como se propone, no puede perjudicar a la jurisdicción de la dicha Sala de Millones.

53. Fernández Albaladejo, "Monarquía y reino en Castilla", 241-283.

54. Con motivo de la perpetuación del servicio de los 8 mil infantes, en 1653. 
El contrato con el rey hecho en Cortes prevalece en derecho a cualquier otro referente legal, porque también hay cédulas reales que lo confirman. Es decir: todo el bagaje jurídico que se ha ido constituyendo con los años alrededor de la Comisión de Millones seguía vigente, ninguna cédula podía anularlo. Añade, el agente del reino:

Y porque el gobernador del Consejo de Hacienda, no pudo determinar la cuestión y controversia entre la Sala de la Comisión y la Contaduría. Pues por las condiciones de millones privativamente toca al Consejo en Sala de Mil y Quinientas la observancia de todas las condiciones, y la en que se da la jurisdicción a la Comisión, y aunque pasó de la Sala del Consejo al de Hacienda, fue con la calidad de conservar la misma jurisdicción, preeminencias y prerrogativas que tenía, de que se despachó cédula.

Felipe III dispuso, en las ordenanzas de 1602, que en las diferencias sobre la jurisdicción entre los tribunales de Hacienda, se ejecutase lo que declarase el presidente ${ }^{55}$. Pero, en 1681, entraba a formar parte de esas diferencias una institución que representaba al reino. La competencia de la Sala de Mil y Quinientas en materia de contravención de las condiciones de millones garantiza que el sistema de referencia de la Comisión continúe siendo el reino, con su alteridad mantiene su independencia del Consejo de Hacienda con respecto a sus leyes y ordenanzas. La preeminencia del gobernador no se traducía en subordinación jurisdiccional, extremo que negaría la naturaleza de la iurisdictio, sustentada en la desobligación del derecho, su orden horizontal. La horizontalidad proviene de la ausencia de compulsión para la iurisdictio, en la naturaleza no vinculante de la ley, pues en el caso de serlo ese orden sería piramidal, circunstancia que no se daba en el antiguo régimen. La hacienda con su imperiosidad y con sus razones supremas de estado no puede jerarquizar y construir una supremacía con imperio, porque existe la Comisión con su jurisdicción privativa. Por tanto, al interior del Consejo de Hacienda había mecanismos legales acordes con los que existían en todo el reino de Castilla, que neutralizaban el principio salus populi suprema lex est, al que apelaba, en 1668, el fiscal de Hacienda. No había una sola y absoluta jurisdicción, una sola voz de Hacienda que pudiese imponer semejante ley, porque era contradicha por sus propios tribunales. La diferenciación entre la hacienda del rey y la hacienda del reino, con su correspondiente separación institucional, para el agente del reino seguía siendo una realidad, que se nos manifiesta con toda su fuerza con motivo de la satisfacción de la deuda, sujeto preferente, eventualmente incluso contra razón y justicia, en la mente de los ministros de Hacienda.

55. San Martín Ocina, "Discurso y representación del fiscal del tribunal de la Contaduría Mayor de Cuentas...", f. 6v. 
En un auto, de 23 de julio, el Consejo de Castilla dictamina que "Por ahora el tribunal de la Contaduría Mayor de Cuentas remita todos los autos originales que hubiere hecho contra Carlos de Santa María sobre que es este pleito a la Sala de Millones". Siete días después, el día 30, Gonzalo de Aponte y Chaves, en una nueva súplica, insistía en que esta causa "...toca su conocimiento privativamente a la dicha Sala de Millones, en fuerza de las condiciones de estos servicios que se pusieron por contrato oneroso y recíproco, y por las cédulas reales de aprobación que se despacharon para su cumplimiento". A ello añadía:

Y porque lo mismo se dispone en las ordenanzas que se hicieron cuando se formó la dicha Sala, y en particular por la 79 se manda que la dicha Sala proceda a la cobranza, nombre ejecutores, y que por ella se haga el pago a los acreedores de la real hacienda, juristas y librancistas.

Las ordenanzas, de 11 de enero de 1657, están en el expediente porque las presentó el agente del reino. Efectivamente, la número 79 establecía las competencias de la Comisión en materia de juros y libranzas ${ }^{56}$. No se trataba solo de que haya ordenanza, sino de que "... así se ha observado desde su creación hasta hoy, sin haber cosa en contrario". Esa ordenanza con el uso estaba dotada de ejecución. La Contaduría no tenía competencia para despachar ninguna comisión, “...mayormente estándose litigando en contradictorio juicio en la dicha Sala por el fiscal con el susodicho sobre la partida de 525 mil maravedíes de una letra que dio, ni lo puede hacer en otro algún caso de esta calidad”. Si, “...para haber observancia, o estilo contra la ley, es necesario, que sea en contradictorio juicio..." ${ }^{57}$, una commissio no debía de proceder y ejecutar de por sí, contra la ley del reino, sin que ese juicio hubiese determinado, sin la observancia del derecho. Con el sistema de referencia del reino, su agente no está defendiendo

56. La número 79 de dichas ordenanzas, es como sigue: "Luego como se fenecieren las cuentas, y se sacaren los alcances a los libros de ellos, con declaración de lo que es líquido, y pertenece a mi real hacienda, y lo que toca a juros, y libranzas que se hubieren dejado de pagar: y lo que fuere litigioso, se ha de notificar a las partes, o a los que tuvieren su poder, para darlas, y dar cuenta en la Comisión para que se mande dar despacho para cobrar lo líquido, y que se haga apercibimiento por el tiempo que pareciere satisfagan las partidas testadas o litigiosas: y pasado se cobre por líquido, y pasado, si no lo hubieren cumplido, se enviarán ejecutores a la cobranza, nombrados por la Comisión, con días, y salarios a costa de los deudores, dando primero fianzas a satisfacción de la Comisión de la cantidad que pareciere, según la que se les mandare cobrar: y habiéndose cobrado, se ha de traer a poder de la persona en quien entraren los alcances, para que de allí se haga pago a mi real hacienda de lo que tocare, y a los juristas, y librancistas de lo que les pareciere, y a los ejecutores se les tomará cuenta luego que hayan acabado sus comisiones, y no han de ser nombrados en segundas, sin haber dado cuenta".

57. "El licenciado don Juan Pérez de Lara, fiscal del Consejo de Hacienda, con el licenciado Juan de Palenzuela y otros consortes, vecinos de la ciudad de Córdoba. Año de 1647”, BN, Porcones, $3 / 30$, f. $13 \mathrm{v}$. 
la parcialidad, sino la universalidad. En efecto, termina Gonzalo de Aponte señalando,

...la determinación universal en todas las causas y negocios de esta calidad es precisa tanto por lo referido, cuanto por excusar las competencias y dudas sobre jurisdicción que cada día se ofrecen de que resultan irreparables daños contra la real hacienda y dispendio de las partes, a que no es justo se dé lugar...

La ley del reino, las condiciones de millones, cédulas reales, y ordenanzas, hacen "determinación universal", también sujetan a derecho, no pueden ser contravenidas desde los tribunales de Hacienda, con actuaciones de hecho, su nueva generalidad administrativa, procedan de la Contaduría o del gobernador. Pero, aquella universalidad también quiere construirse para substraer a la ley del reino, y a la hacienda con su apremio, de la competencia jurisdiccional, principal garantía de contravención que sujeta a los tribunales a derecho. La competencia era asimismo una garantía de la constitución del reino. Con ello su agente no está defendiendo necesariamente su anulación, sino no someter a duda su jurisdicción plena. El rey podía mandar que no se forme competencia, como lo hace solo tres años después, en 1684, con respecto a la Junta de Comercio ${ }^{58}$. Una de las motivaciones que indujeron a la agregación, en 1658, lo dice el rey, fue "...el poderse excusar un tribunal, y con él la diversidad de ministros, y costas que causan, y las competencias de jurisdicción, que de ordinario se ofrecen". El mismo argumento que se utilizó para entregar a los corregidores las administraciones de millones. Un gasto superfluo que servía de amparo a una garantía jurídica como la competencia jurisdiccional no podía mantenerse. Pero ello no se erradicó con la agregación. Por tanto, desde los tribunales de Hacienda la contravención a la que abocaba la competencia seguía siendo un instrumento jurídico de actuación que introducía aquella duda, mermando la condición de tribunal supremo de la Sala de Millones. Porque podía serle útil, la hacienda no podía abrirse camino sin contradecir, competir, contravenir.

El Consejo de Castilla, en Sala de Mil y Quinientas, por auto de 12 de septiembre, dictaminó “...se traiga este pleito...”, “...y no se haga novedad

58. Argumentaba el monarca, "porque a los consejos, chancillerías, tribunales, jueces, y justicias de estos reinos los inhibí, y he por inhibidos, y les mandé no se entrometan a conocer de ello con ningún pretexto; porque solo la Junta ha de conocer única y privativamente de todo lo referido, y lo anexo, y dependiente. Para cuyo efecto le di y concedí tan bastante poder, facultad, y jurisdicción, como de derecho es necesario, y en tal caso se requiere, con sus incidencias, y dependencias. Y para excusar competencias (que tanto embarazan el curso de los negocios) derogué todos y cualesquiera fueros que perteneciesen, o pudieren pretender los interesados a título de cualquier exención que tuviesen, o debiesen gozar. Y mandé, que sobre ello no se formase, ni admitiese competencia alguna" (Madrid 30 de enero de 1684), BN, VE, 25/33.

Chronica Nova, 46, 2020, 177-212 - http://doi.org/10.30827/cnova.v0i46.6644 
contra Carlos de Santa María, ni sus bienes”. Se suspendía con ello la deuda y el libramiento. Si esta circunstancia satisfacía una reivindicación secular del reino, podemos enmarcarlo en una tendencia, que se manifestó al final del reinado, de independencia con respecto a los hombres de negocios ${ }^{59}$. Además, ello venía a unirse a las dificultades por las que venía pasando la casa de Andrea Piquinoti durante estos años para cobrar sus libranzas ${ }^{60}$.

El Consejo de Castilla, por auto, de 19 de septiembre, confirma el de 23 de julio, por el que había mandado remitir los autos originales a la Sala de Millones, añadiendo, "Y en todo lo demás comprehendido en las condiciones de millones se remite su conocimiento a la dicha Sala de Millones". El Consejo hacía valer la legalidad del reino, la que él custodiaba y estaba latente en la Sala. El 9 de agosto, Francisco de Gálvez, fiscal del Consejo de Hacienda, pide se enmiende el auto de 23 de julio. En su súplica alega,

...porque la causa de proceder por el dicho tribunal de Cuentas contra Carlos de Santa María, no toca ni puede tocar en ningún caso ni instancia a la Sala de Millones, porque la deuda procede de efecto decretado que como tal se consignó por el dicho Consejo de Hacienda a las casas de Andrea Piquinoti y Manuel Cortizos, cuya satisfacción se trata de reconocer si se dio por el dicho Carlos de Santa María...

Ante la pregunta, sobre el pago a juristas y librancistas, “¿Quién coopera contra las órdenes de su majestad en estos pagos?", responde Alonso Barbero que, "Los contadores de la intervención, cuenta y razón" ${ }^{61}$. En esta ocasión esa cooperación procedía de un vecino de Medina del Campo. El depositario de quiebras de millones, Domingo González Villegas, en una súplica pide “...que los contadores que están tomando la cuenta informen de los recados y con vista de ellos se mande hacer buena dicha cantidad...". Los cuales confirman en un informe el pago hecho por el administrador de millones a Carlos de Santa María. Si hay que considerar que "...el acreedor que pretende la cobranza, cabe en el valor general de la renta, y no en lo cobrado de ella...", y en los millones, como en los cuatro medios por ciento, servicio ordinario, o papel sellado, había régimen de primera, segunda (se consideraban antiguos), tercera, cuarta, quinta y sexta situación (que se consideraban modernos) ${ }^{62}$,

59. Juan Antonio Sánchez Belén, La política fiscal en Castilla durante el reinado de Carlos II (Madrid: Siglo XXI de España, 1996), 124-125.

60. "Manifiesto de los cargos que resultan contra don Francisco María Piquinoti, y don Juan de Guzmán, de la administración de la casa del señor Andrea Piquinoti, desde 4 de diciembre de 1679, hasta 24 de julio de $1681 \ldots$.., BN, Porcones, $293<2>(8)$.

61. Barbero Teniente, Luz y claridad, 4-5.

62. Barbero Teniente, Luz y claridad, 11, 14. 
según ello no se estaría disputando el cabimiento de la deuda, que no sería imputable a los contadores. Habría oposición abierta a su satisfacción, que es el verdadero motivo de este pleito, la cual es posible porque divide a la Comisión y al Consejo de Hacienda, separando la legalidad fiscal y contable en dos referentes diferenciados y contrapuestos. El agente del reino, apoyado por el Consejo de Castilla, estaba bloqueando la deuda, que los millones se pusieran a disposición de los hombres de negocios, que el cabimiento general fuese entera paga con independencia de la legalidad del reino. No se trataba solo de los asentistas, pues había una corriente de opinión contraria a que los juros se situasen en los tributos del reino, circunstancia que se remontaba a 1626, cuando la corona obtuvo el permiso para vender juros situados sobre los servicios ${ }^{63}$, o en 1632, cuando buena parte del incremento del servicio de millones se destinó a la atención de la deuda ${ }^{64}$. Como respuesta a esta situación, un regidor de Cuenca piensa,

Si están cargados [los juros] sobre las contribuciones concedidas por el reino, éstas deben ser temporales, y no perpetuas, pues la causa que hace lícito el tributo, es la necesidad con que se pide, y luego al punto que cesa la necesidad, debe también cesar el tributo. Luego haber vendido estas rentas a los juristas es haber perpetuado el tributo, aun cuando no haya necesidad, que obligue a su contribución, como hoy está sucediendo, pues no teniendo guerras ningunas, se pagan los mismos tributos, que cuando las había ${ }^{65}$.

La deuda se comportaba así como una fiscalidad paralela ${ }^{66}$, con la peculiaridad de crear una obligación que quebrantaba los principios pactistas del auxilium, su desobligación. Con la legalidad del reino se trataba de salvaguardarla. Si a ello añadimos que las consignaciones son rapiña de manos de los hombres de negocios, la determinación de la Sala o Comisión de Millones podía encontrar un estado de opinión favorable, que la vinculaba con los intereses del reino:

Luego se advierta, que siempre los hombres de negocios (que con este magnífico nombre excusan de mercaderes) se han aprovechado de las consignaciones, y de

63. Fernández Albaladejo, "Monarquía, Cortes y cuestión constitucional”, 298. Fernández de Pinedo y Fernández, "Fiscalidad y absolutismo en Castilla", 48. José Ignacio Andrés Ucendo, "Una herencia de Felipe II: los servicios de millones en Castilla durante el siglo XVII," en Felipe II (1527-1598): Europa y la monarquía católica, ed. José Martínez Millán (Madrid: Parteluz, 1998), 2:60. Sanz Ayán, "La evolución de los juros", 151.

64. Artola, La hacienda del antiguo régimen, 141.

65. "Memorial dirigido a la reina doña Mariana de Austria por don Antonio Muñoz de Castilblanque, regidor perpetuo de la ciudad de Cuenca..." (1669), BN, VE, 181/55, f. 2v.

66. Fortea, "Monarquía, Cortes y ciudades", 340.

Chronica Nova, 46, 2020, 177-212 - http://doi.org/10.30827/cnova.v0i46.6644 
juros que se les han dado, en resguardo, y de otras adehalas, vendiéndolo todo para prevenir el dinero que han de proveer $^{67}$.

En un discurso, del reinado de Felipe IV, se denunciaba:

Esto supuesto no puede haber negociación más odiosa, más perjudicial, ni más digna de remedio, de la que resulta de los asientos, cuyos contratos son usurarios, padecen lesión enormísima, y contienen finalmente los perjuicios que aquí se refieren, que son los mayores que pueden haber en imaginación humana, y bastantes, a que sobre las cargas precisas (a que no se puede volver cara) se acabe de agotar con ellos el real patrimonio de vuestra majestad ${ }^{68}$.

Los asentistas no ofrecen un servicio, sino un deservicio. Los privilegios y adehalas que disfrutan están desprovistos de razón jurídica, su servicio recompensa no se incorpora a lo que es común, no alimenta el pacto fiscal. La consignación de esta deuda en los millones venía a negar su trasfondo contractual, un rey obligado con el reino. El odio que suscitan entre los súbditos los hombres de negocios, lo expresa el autor denunciando,

...la ostentación con que se portan los asentistas, desproporción de sus gastos, mayores que los de ningún Grande, y los gruesos caudales con que se hallan, sin haber entrado con ningunos, que uno y otro sale de la hacienda de vuestra majestad, ultra; las mercedes honoríficas que han obtenido de su real grandeza. Todo esto, señor, ocasiona suma admiración, y obliga a que con igual desvelo se trate de su remedio.

Haciéndose eco de esta inquina, con su arbitrio se vendría a satisfacer la vieja aspiración del reino — que recogen otros arbitrios, como, por ejemplo, el de los erarios y montes de piedad ${ }^{69}$, pues “...quedaría totalmente extinguida la

67. "No sé cómo dormimos ni reposamos los criados y vasallos de vuestra majestad...", [reinado de Carlos II, posterior a 1692], RAH, 9/3649(12).

68. "Discurso y apuntamientos sobre los daños que se siguen a la real hacienda; de las provisiones, y asientos de que se encargan los hombres de negocio, y medios, que para excusarlos se proponen a su majestad, por un vasallo celoso de su servicio" (Madrid, en el texto se cita la fecha de 1639), BN, VE, $186 / 55,9$.

69. Manuel López Pereira, "La elección que el rey nuestro señor ha hecho en V.E. para bien universal de estos reinos..." (Madrid, 4 de abril de 1623), BN, Porcones, 57/36, ff. 1v-2r. Joseph Camerino, por su parte, se hace eco del sentir contrario, pues objeta que, con su arbitrio, “...se dirá, que se destruye a los hombres de negocios, y asentistas, que conviene se sustenten, amparen, y defiendan en las monarquías, y gobiernos bien concertados, por ser las mejores oficinas de sus socorros...", "Último aviso de Joseph Camerino, procurador de los reales Consejos, para la ejecución de su primera proposición, que da humilde al reino junto en Cortes, para el alivio común expuesto por los logros del afecto, al desaire, que se previene al talento, si se despreciare por inútil", [reinado de Felipe IV], BN, Porcones, 99/24, f. 2r. 
necesidad de los asentistas, tan en servicio de vuestra majestad, y bien de estos reinos, como lo manifiestan los rigurosos daños que sus contratos han resultado a la real hacienda" 70 . Si no erradicar, al menos se podía reducir el mal de los asentistas, su poder, la imperiosidad o prelación de su deuda, su cautiverio - a este respecto, la planta de primero de enero de 1688, colocará a los asentistas en tercer lugar en la distribución de las rentas en los partidos, por detrás de los juros, que ocupaban el segundo lugar, mientras que la causa pública ocupaba el primero $^{71}$ - , que la hacienda del reino estuviese a su disposición. Estas ideas recogidas por el arbitrismo tenían inducción jurídica en la representación del reino, y, en 1681, curso institucional en la Sala de Millones — respaldada en este punto por el Consejo de Castilla. Ello, no obstante que el corregidor de Medina del Campo, opuesto al administrador de millones, a su forma de administración independiente de la iurisdictio, aprovechando la disputa con la Contaduría, no la confirmaba, pues ponía en práctica la desobediencia jurídica, la constatación de que el sistema de referencia legal de la Sala de Millones - como por otra parte del propio Consejo de Hacienda-, podía revelarse como ambivalente, a favor o contra los intereses del reino, cuya representación estaba por tanto dividida y sujeta a interpretación.

El fiscal de Hacienda, argumentando que la consignación “....al depositario de millones ya le estaba hecha buena en su cuenta en virtud de autos de la dicha Sala de Millones, que es el conocimiento que pudo tocarle, y no el que pretende, que es ya diferente efecto, y de diferente deudor". A ello se añadía haber habido resistencia de hecho:

Y porque con esto concurre la criminalidad pendiente contra el dicho Carlos de Santa María, por los malos tratamientos que hizo al juez ejecutor del dicho tribunal de Cuentas, de que privativamente debe conocer, por ser hechos a ministro enviado por él.

Para el fiscal también había cuestiones técnicas, como no estar en estado el pleito para pronunciarse el auto de 23 de julio, y tener introducido artículo con debido pronunciamiento. Argumentos habituales en otros pleitos, que solían alegarse a favor de la propia pretensión.

70. "Discurso y apuntamientos sobre los daños que se siguen a la real hacienda...", 16.

71. No obstante que, advierte Barbero Teniente, la dotación precipua de la causa pública, “...no es más que un nombre equivocado, y que su majestad le prefiere, pues procede de la raíz, producto, y ingreso del valor de los juristas...", Luz y claridad, 23-24, y 25. 


\section{CONCLUSIÓN}

Hasta aquí llega el pleito de 1681. Con él, como sucedía al comenzar el reinado, hemos visto a los tribunales de Hacienda enfrentados entre sí, reproduciendo las competencias que se daban entre los distintos Consejos y tribunales de justicia. Con esas competencias se estaba activando una garantía del derecho. La independencia y soberanía de la iurisdictio, con la desobligación del ius, son los mismos fundamentos que afloraban, con una peculiaridad, pues con ella estaba en juego el mantenimiento del sistema de referencia legal del reino, su soberanía, su voz y representación. La agregación de 1658 no acalló esa voz, pues su mantenimiento continuó dando batalla pleiteando, apostando por una Sala o Comisión de Millones acorde con los intereses del reino, los de una hacienda de defensa propia diferenciada de la hacienda del rey. Se trataba de salvaguardar todo un sistema de referencia legal con su alternativa de ejecución, que la desobligación del derecho habilitaba, cuyo valor era la variedad de la iurisdictio. Ello nos pone en evidencia la doble significación de la Comisión, según sea el reino, con el Consejo de Castilla; o el Consejo de Hacienda, con la Contaduría, quien interprete su sistema de referencia legal. Los súbditos con los diferentes recursos que ofrecía el derecho podían utilizar ambas para contravenir según su conveniencia. Por lo que esos recursos podían neutralizar en la corte la compulsión que se quería construir desde Hacienda con el despliegue de las administraciones generales de millones en las provincias. Mientras que el comportamiento del corregidor de Medina del Campo, opuesto a éstas últimas, quien le negaba obediencia a la Comisión, nos muestra las aparentes contradicciones que semejante ambivalencia acarreaba, porque si quería adscribirse, y se estaba haciendo, al regnum, no era obvio que con ello la Sala de Millones vertebrase la representación de las ciudades. Y es que aquí estaban los administradores de millones con su nueva forma de acción administrativa que trastornaba el orden de la iurisdictio, su calidad de vocera de los intereses locales, y su representación de la comunidad. Pero aquellas "contradicciones" encontraban coherencia en la desobligación del derecho que las generaba, el principio constitutivo del orden legal; se salvaba el derecho. Por tanto, si se contradecía y contravenía, se estaba llamando a la misma desobligación que habilitaba los pleitos. Es así como la recuperación de la Comisión como institución del reino independiente fue concebible y considerada factible por sus actores, durante el reinado de Carlos II, pleiteando allí donde fuese necesario, bien directamente sobre la agregación, con la prosecución del pleito de 1663, bien sobre sus consecuencias, con el pleito de 1681. Si ese era el marco jurídico, al pleitear se estaba también sometiendo la ley fiscal a justicia, de su ejecución se trataba. Y si se sometía al proceso, con el objetivo de salvar la interpretación adecuada y favorable de todo un sistema de referencia legal privativo, con sus contraprestaciones de servicio - las del auxilium-, de forma simultánea se le estaba negando a esa ley, su naturaleza unívoca, absoluta, 
vinculante, manteniéndose por el contrario su naturaleza relativa, conforme al, esta vez verdadero, poder regular y ordinario — cuya obligación desobliga-, del monarca. La consecuencia que ello tenía en las relaciones entre rey y reino, es que incluso un rey desobligado de sus compromisos contractuales, como querían algunos ministros, no hacía de él un soberano absoluto. Al contrario, siendo esa contingencia una probabilidad legal entre otras, lo seguía manteniendo atado al derecho, porque la desobligación del ius, que es común, ni destruye, ni separa, ni crea la compulsión; autoriza y enlaza confirmando cada sistema de referencia con sus leyes y principios.

\section{BIBLIOGRAFÍA:}

Andrés Ucendo, José Ignacio. "Una herencia de Felipe II: los servicios de millones en Castilla durante el siglo XVII". En Felipe II (1527-1598): Europa y la monarquía católica, editado por José Martínez Millán, 4 vols., 2:53-66 Madrid: Parteluz, 1998.

Artola, Miguel. La hacienda del antiguo régimen. Madrid: Alianza Editorial/ Banco de España, 1982.

Bermejo Cabrero, José Luis. "En torno a las Cortes del antiguo régimen". AHDE, $n^{\circ}$ 63-64 (1993-1994): 149-234.

Boscheron des Portes, Charles-Bon-François. Histoire du Parlement de Bordeaux depuis sa création jusqu'à sa suppression (1451-1790). Bordeaux: Hachette livre-BNF, 1877.

Carretero Zamora, Juan Manuel. Cortes, monarquía, ciudades. Las Cortes de Castilla a comienzos de la época moderna (1476-1515). Madrid: Siglo XXI de España, 1988.

Castellano, Juan Luis. Las Cortes de Castilla y su Diputación (1621-1789). Entre pactismo y absolutismo. Madrid: Centro de Estudios Constitucionales, 1990.

Dios, Salustiano de. "La evolución de las Cortes de Castilla durante los siglos XV-XVII". En Hispania. Entre derechos propios y derechos nacionales. Atti dell'incontro di studio. Firenze-Lucca, 25, 26, 27 maggio 1989, editado por Bartolomé Clavero, Paolo Grossi, Francisco Tomás y Valiente, 2 vols., 1:593-755. Milano: Giuffrè Editore, 1990.

Domínguez Ortiz, Antonio. "Concesiones de votos en Cortes a ciudades castellanas en el siglo XVII." AHDE, no 31 (1961): 175-186.

Fernández Albaladejo, Pablo. "Cortes y poder real: una perspectiva comparada." En Fragmentos de monarquía. Madrid: Alianza, 1992.

- "La resistencia en las Cortes". En Fragmentos de monarquía. Madrid: Alianza, 1992.

- "Monarquía, cortes y cuestión constitucional en Castilla durante la Edad Moderna." En Fragmentos de monarquía. Madrid, Alianza: 1992. 
— "Monarquía y reino en Castilla 1538-1623". En Fragmentos de monarquía. Madrid: Alianza, 1992.

Fernández de Pinedo y Fernández, Emiliano. "Fiscalidad y absolutismo en Castilla en la primera mitad del siglo XVII”. En Política y Hacienda en el Antiguo Régimen. II Reunión científica Asociación Española de Historia Moderna 1992, editado por José Ignacio Fortea Pérez, Carmen María Cremades Griñán, 2 vols., 1:33-51. Murcia: Ediciones de la Universidad de Murcia, 1993.

Fortea, José Ignacio. "Trayectoria de la Diputación de Cortes", Las Cortes de Castilla y León en la Edad Moderna. Actas de la segunda etapa del Congreso Científico sobre la Historia de las Cortes de Castilla y León, Salamanca, del 7 al 10 de abril de 1987. Valladolid: Cortes de Castilla y León, 1989.

_ "Reino y Cortes: el servicio de millones y la reestructuración del espacio fiscal en la Corona de Castilla (1601-1621)", Política y Hacienda en el Antiguo Régimen. II Reunión científica Asociación Española de Historia Moderna 1992, editado por José Ignacio Fortea Pérez, Carmen María Cremades Griñán, 2 vols., 1:53-82. Murcia: Ediciones de la Universidad de Murcia, 1993.

- "Monarquía, Cortes y ciudades en la Corona de Castilla durante la Edad Moderna”. En Actes del 53 $3^{e}$ Congrés de la Comissió Internacional per a l'Estudi de la Història de les Institucions Representatives i Parlamentàries. Coordinado por Jaume Sobrequés, Joseba Agirreazkuenaga, Mercè Morales, Mikel Urquijo, M. Cisneros, 2 vols., 1:305-345. Barcelona: Parlament de Catalunya y Museu d'Història de Catalunya, 2005.

- Las Cortes de Castilla y León bajo los Austrias: una interpretación. Valladolid: Junta de Castilla y León, 2008.

García-Badell Arias, Luis María. "La sucesión de Carlos II y las Cortes de Castilla". Cuadernos de Historia del Derecho, no 13 (2006): 111-154.

Garzón Pareja, Manuel. La hacienda de Carlos II. Madrid: Ministerio de Hacienda, 1981.

González Alonso, Benjamín. "Las Comunidades de Castilla y la formación del estado absoluto", Sobre el estado y la administración de la Corona de Castilla en el antiguo régimen. Madrid: Siglo XXI de España, 1981.

Hendricks, Charles David. "Charles $V$ and the 'Cortes' of Castile. Politics in Reinaissance Spain”. Tesis Doctoral, Cornell University, 1976.

Heras, José Luis de las. "La jurisdicción del Consejo de Hacienda en tiempos de los Austrias". En Estado y fiscalidad en el antiguo régimen, Actas del 1 Simposium Internacional: Estado y Fiscalidad en el Antiguo Régimen, editado por Carmen María Cremades Griñán, 117-127. Murcia: Universidad de Murcia, 1989.

Jago, Charles J. "Fiscalidad y cambio constitucional en Castilla (1601-1621)", En Política y Hacienda en el Antiguo Régimen. II Reunión científica Asociación Española de Historia Moderna 1992, coordinado por José Ignacio Fortea Pérez, Carmen María Cremades Griñán. Moratalla: Universidad de Murcia, 1993. 
Pérez, Joseph. La revolución de las Comunidades de Castilla (1520-1521). Madrid, 1979.

Sánchez Belén, Juan Antonio. La política fiscal en Castilla durante el reinado de Carlos II. Madrid, Siglo Veintiuno de España, 1996.

Sanz Ayán, Carmen. "Consolidación y destrucción de patrimonios financieros en la edad moderna: los Cortizos (1630-1715)". En Fortuna y negocios: formación y gestión de los grandes patrimonios (siglos XVI-XX), coordinado por Ricardo Robledo Hernández, Hilario Casado Alonso, 73-98. Valladolid: Universidad de Valladolid, 2002.

- "Presencia y fortuna de los hombres de negocios genoveses durante la crisis hispana de 1640". Hispania, LXV, no 219 (2005): 91-114.

— "La evolución de los juros durante el reinado de Carlos II." En La decadencia de la monarquía hispánica en el siglo XVII. Viejas imágenes y nuevas aportaciones. Editado por María del Carmen Saavedra, 147-164. Madrid: Editorial Biblioteca Nueva, 2016.

Thompson, Irving A. Anthony. "Crown and Cortes in Castile, 1590-1665." En Crown and Cortes. Government, Institutions and Representation in EarlyModern Castile, VI. 1993.

- "The end of the Cortes of Castile". En Crown and Cortes. Government, Institutions and Representation in Early-Modern Castile, VII, 125-133. London-New York: Routledge, 1993.

Tomás y Valiente, Francisco. "La Diputación de las Cortes de Castilla (15251601)". En Gobierno e instituciones en la España del antiguo régimen. Madrid: Alianza, 1982. 